\title{
Inhibition of NF-KB prevents the acidic bile-induced oncogenic mRNA phenotype, in human hypopharyngeal cells
}

\author{
Dimitra P. Vageli ${ }^{1}$, Sotirios G. Doukas ${ }^{1}$ and Clarence T. Sasaki ${ }^{1}$ \\ ${ }^{1}$ The Yale Larynx Laboratory, Department of Surgery, Yale School of Medicine, New Haven, CT, USA \\ Correspondence to: Clarence T. Sasaki, email: clarence.sasaki@yale.edu
}

Keywords: bile acids; NF-kB inhibitor; hypopharyngeal carcinogenesis; mRNA phenotype; laryngopharyngeal reflux

Received: June 13, 2017

Accepted: November 01, 2017

Published: December 12, 2017

Copyright: Vageli et al. This is an open-access article distributed under the terms of the Creative Commons Attribution License 3.0 (CC BY 3.0), which permits unrestricted use, distribution, and reproduction in any medium, provided the original author and source are credited.

\section{ABSTRACT}

Bile-containing gastro-duodenal reflux has been clinically considered an independent risk factor in hypopharyngeal carcinogenesis. We recently showed that the chronic effect of acidic bile, at pH 4.0, selectively induces NF- $\kappa$ B activation and accelerates the transcriptional levels of genes, linked to head and neck cancer, in normal hypopharyngeal epithelial cells. Here, we hypothesize that NF- $\kappa$ B inhibition is capable of preventing the acidic bile-induced and cancer-related mRNA phenotype, in treated normal human hypopharyngeal cells. In this setting we used BAY 11-7082, a specific and well documented pharmacologic inhibitor of NF- $\kappa B$, and we observed that BAY 11-7082 effectively inhibits the acidic bile-induced gene expression profiling of the NF- $\kappa$ B signaling pathway (down-regulation of 72 out of 84 analyzed genes). NF- $\kappa$ B inhibition significantly prevents the acidic bile-induced transcriptional activation of NF- $K$ B transcriptional factors, RELA (p65) and c-REL, as well as genes related to and commonly found in established HNSCC cell lines. These include anti-apoptotic bcl-2, oncogenic STAT3, EGFR, $\triangle N$ N63, TNF- $a$ and WNT5A, as well as cytokines IL-1 $\beta$ and IL6. Our findings are consistent with our hypothesis demonstrating that NF- $\kappa B$ inhibition effectively prevents the acidic bile-induced cancer-related mRNA phenotype in normal human hypopharyngeal epithelial cells supporting an understanding that NF- $\kappa$ B may be a critical link between acidic bile and early preneoplastic events in this setting.

\section{INTRODUCTION}

Many forms of Head and neck squamous cell carcinoma (HNSCC) have been attributed to known risk factors such as tobacco smoking and alcohol consumption [1-3], whereas extra-esophageal or laryngopharyngeal reflux disease (ERD or LPR) is now also considered to be an independent risk factor in laryngopharyngeal carcinogenesis [4-6]. Although the clinical prevalence and magnitude of gastroduodenal reflux is not fully known, there seems to be growing evidence that approximately $50 \%$ to $86 \%$ of patients with gastro-esophageal reflux disease (GERD) present with mixed gastric and duodenal fluids (bile acids) in their refluxates [7-9]. According to Covington et al bile-containing enterogastric reflux is much more common than previously appreciated [10]. Gali et al. showed that during LPR gastroduodenal fluid (GDF) reaches the epithelium of the upper aerodigestive tract and contributes to the development of inflammatory and neoplastic events [6]. The precise role of bile-containing GDF in hypopharyngeal cancer and the underlying mechanism of its carcinogenic effect remain unclear. In the initiation and progression of HNSCC, several oncogenic pathways have been identified. These commonly include EGFR/Ras/RAF/MAPK, Akt/PI3K/

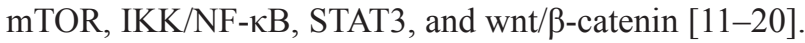
In this setting, our recent in vitro and in vivo explorations demonstrate that extra-esophageal reflux may play a role in laryngopharyngeal carcinogenesis, mediated by NF- $\kappa \mathrm{B}$ [21-23]. Recently published data demonstrate that bile, particularly at $\mathrm{pH} \leq 4.0$ is capable of inducing $\mathrm{NF}-\kappa \mathrm{B}$ activation and oncogenic mRNA phenotype [21, 22]. Specifically, bile at molar concentrations previously reported in symptomatic GERD patients [8] at $\mathrm{pH} \leq 4.0$ can induce significant activation of NF- $\mathrm{kB}$ and related genes associated with oncogenic function, in both cultured normal hypopharyngeal keratinocytes and premalignant lesions of exposed murine laryngopharyngeal mucosa 
[22]. According to Ulualp et al. studies of 24-hour ambulatory $\mathrm{pH}$ monitoring in the pharynx of patients, a drop below pH 4.0 is not uncommon and is considered diagnostic of a reflux event [24], suggesting that acid may contribute to GDF-induced inflammatory and neoplastic events. Moreover, Dvorak et al. showed that bile at acidic $\mathrm{pH}$ may potentially induce DNA damage [25]. Here we hypothesize that NF- $\mathrm{BB}$ inhibition is capable of preventing the acidic bile-induced and cancer-related mRNA phenotype in treated normal hypopharyngeal cells, in vitro, further emphasizing the understanding that $\mathrm{NF}$ $\kappa \mathrm{B}$ is a critical link between acidic bile and preneoplastic events.

Nuclear factor-kappB is widely considered a key mediator between chronic inflammation and cancer. Many studies underscore the understanding that NF- $\kappa B$ regulates the transcriptional activation of genes with antiapoptotic function, cell proliferation, tumor initiation and progression, as well as genes mediating epithelial mesenchymal transition (EMT) [11-13]. Lee at al suggest that the constitutive activation of NF- $\mathrm{KB}$ provides an alternative mechanism for head and neck carcinogenesis [26]. Specifically, they show that there are subtypes of head and neck cancer that demonstrate constitutive activation of NF- $\mathrm{BB}$ with significant transcriptional alterations in clusters of NF- $\mathrm{\kappa B}$ target genes.

The canonical pathway of NF- $\kappa B$ activation includes phosphorylation of IкB- $\alpha$, that leads to nuclear translocation of heterodimers p50/Rela or p50/cRel, and consequent binding to the promoters of target genes and regulating their expression. NF- $\mathrm{KB}$ activation induces a signaling pathway by accelerating the expression of several receptors, ligands and transcriptional factors that regulate NF- $\kappa B$ activation and immune response through $\mathrm{NF}-\kappa \mathrm{B}$, while inhibition of NF- $\kappa \mathrm{B}$ negatively affects the gene expression profiling of the NF- $\mathrm{KB}$ signaling pathway, and has been considered promising for improving anticancer therapies [27]. The inhibition of NF- $\mathrm{KB}$ through BAY 11-7082 [(E)-3-(4-methylphenylsulphonyl)-1propenenitrile], has been well documented by others by inhibiting IкB- $\alpha$ phosphorylation, blocking proteosomal

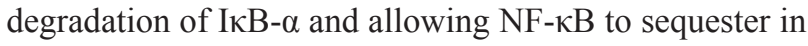
the cytoplasm in an inactivated state [28-30]. Selective inhibition of $\mathrm{NF}-\kappa \mathrm{B}$ and its related transcriptional phenotypes may clarify the role of NF- $\mathrm{KB}$ as a critical component linking acidic bile to preneoplastic events.

\section{RESULTS}

\section{BAY 11-7082 inhibits the acidic bile-induced NF- $\kappa B$ activation and bcl-2 cytoplasmic accumulation in normal human hypopharyngeal cells}

We observed that the nuclear localization of phospho-NF-kB (p-p65 S556) was inhibited by BAY 117082, in human hypopharyngeal primary cells (HHPC) exposed to acidic bile at $\mathrm{pH}$ 4.0. This observation was characterized by decreased p-p65 nuclear staining by using an immunofluorescence (IF) assay (Figure 1). We also found that BAY 11-7082 inhibited p-p65 nuclear localization in HHPC exposed to acid alone ( $\mathrm{pH} 4.0)$. This observation was also characterized by decreased p-p65 nuclear staining, implying that NF- $\mathrm{KB}$ inhibitor blocks acid-induced p-p65 translocation to the nucleus. However, we observed that BAY 11-7082 induced minimal changes in nuclear staining of p-p65 in HHPC exposed to bile at $\mathrm{pH} 7.0$ or to neutral control (Figure 1), compared to HHPC at $\mathrm{pH}$ 4.0. Finally, we showed that cells exposed to DMSO, exhibited patterns of weak nuclear p-p65 staining like that of the untreated control, implying that the solubilizing vehicle for BAY 11-7082 had no effect on p-p65 localization or expression (see Supplementary Figure 1 online).

Staining with CK14 supports the observation that a proportion of $\mathrm{p}-\mathrm{p} 65$ remains in the cytoplasmic compartment of HHPC treated by bile at $\mathrm{pH} 7.0$ with inhibitor. In contrast, NF- $\mathrm{kB}$ inhibitor seems to reduce both cytoplasmic and nuclear p-p65 levels in HHPC treated by bile at $\mathrm{pH} 4.0$, implying reduced protein expression in this group.

Statistical analysis revealed that BAY 11-7082 effectively reduced total p-p65 (Ser536) levels in treated HHPC, with significant difference in those exposed to acid alone ( $\mathrm{pH} 4.0)(p=0.037)$, and particularly to acidic bile ( $\mathrm{pH} 4.0)(p=0.0026)$, supporting the contribution of acid ( $\mathrm{pH} 4.0)$ in NF- $\mathrm{kB}$ activation of treated cells (Figure 1B) ( $t$-test; means $\pm \mathrm{SD}$; multiple comparisons by HolmSidak). These data demonstrate that acidic bile-related $\mathrm{NF}-\kappa \mathrm{B}$ activation and NF- $\mathrm{\kappa B}$ expression are substantially reduced by BAY 11-7082, in treated HHPC.

To further analyze the effect of BAY 11-7082 on NF$\kappa \mathrm{B}$ activation and bcl-2 expression, we performed a western blot analysis for phospho-NF-kB (p65 S356) $(\sim 65 \mathrm{kDa})$, phospho-inhibitor kappaB-a (p-IкB- $\alpha$ S32/S36) ( 40 kDa) and bcl-2 $(\sim 28 \mathrm{kDa})$, using Histone $1(\sim 30 \mathrm{kDa})$ and $\beta$-actin $(\sim 37 \mathrm{kDa})$ for normalization of the expression, in nuclear and cytoplasmic protein fractions of the treated cells (Figure 2). (i) We observed an inhibition of NF- $\mathrm{KB}$ activation and bcl-2 cytoplasmic accumulation in both HHPC and HHK exposed to bile at $\mathrm{pH} 4.0$ with BAY 11-7082, compared to cells exposed to bile at $\mathrm{pH} 4.0$ without BAY 11-7082. This inhibition was evidenced by significantly decreased phospho-NF- $\mathrm{KB}$ nuclear levels in cells exposed to bile at $\mathrm{pH} 4.0$ (Figure 2A-a, 2B-a), accompanied by reduced cytoplasmic p-IкB- $\alpha$ levels (Figure 2A-b, 2B-b) and cytoplasmic bcl-2 ratios (Figure 2A-c, 2B-c) $(p<0.05$; by paired $t$-test; Graph Pad Prism 6.0). (ii) We also found a decrease in NF- $\kappa$ B activation in HHPC exposed to acid (pH 4.0) plus BAY 11-7082, compared to those exposed to acid alone, without NF- $\mathrm{KB}$ inhibitor, demonstrating that NF- $\kappa \mathrm{B}$ inhibitor suppressed NF- $\kappa \mathrm{B}$ activation induced by low $\mathrm{pH}$ (Figure 2A-a, 2B-a). This event was evidenced by 
a decrease of cytoplasmic p-IкB- $\alpha$ levels in cells exposed to acid alone ( $\mathrm{pH} 4.0)$ (Figure 2A-b, 2B-b). (iii) On the other hand, we found minimal changes of nuclear $N F-\kappa B$ (Figure 2A-a, 2B-a) and cytoplasmic p-IкB- $\alpha$ (Figure 2Ab, 2B-b) levels in both HHPC and HHK treated with bile at pH 7.0 plus BAY 11-7082, compared to those exposed to bile at pH 7.0 without BAY 11-7082, again supporting our observations by IF assay.

Further, we observed that HHPC and HHK exposed to bile plus inhibitor at $\mathrm{pH} 4.0$ demonstrated the lowest relative expression ratios (with/without inhibitor) of activated NF- $\kappa$ B (Figure 3A-a, 3B-a), cytoplasmic $p-\mathrm{I} \kappa \mathrm{B}-\alpha$ levels (Figure 3A-b. 3B-b), and bcl-2 (Figure 3A-c, 3B-c), with a significant difference compared to neutral control ( $\mathrm{pH} 7.0)$, neutral bile $(\mathrm{pH} 7.0)$ or acid alone $(\mathrm{pH} 4.0)(p<$ 0.05; ONE WAY ANOVA, Kruskal-Wallis, GraphPad 6.0).

Taken together, BAY11-7082 effectively prevented the bile-induced activation of NF- $\mathrm{\kappa B}$ at $\mathrm{pH}$ 4.0. Moreover, we showed that the effect of BAY 11-7082 resulted in a significant reduction of bile-induced cytoplasmic bcl-2 accumulation, particularly at acidic $\mathrm{pH}$. NF- $\kappa \mathrm{B}$ inhibition was significantly more effective in preventing NF- $\kappa \mathrm{B}$ activation and bcl-2 expression in cells repetitively exposed to bile at $\mathrm{pH} 4.0$, compared to bile at $\mathrm{pH} 7.0$ or acid alone ( $\mathrm{pH} 4.0)$.

\section{BAY 11-7082 inhibits the acidic bile-induced NF- $\kappa \mathrm{B}$ transcriptional activity at $\mathrm{pH} 4.0$ in treated normal human hypopharyngeal cells}

Luciferase assay revealed lower NF- $\kappa \mathrm{B}$ transcriptional activity in both HHPC and HHK exposed to
BAY 11-7082, compared to those cells treated without NF$\kappa \mathrm{B}$ inhibitor, as shown by the negative ratios of relative $\mathrm{NF}-\kappa \mathrm{B}$ activity in Figure 4. HHK and particularly HHPC (Figure 4A-a,b), exposed to bile at pH 4.0 plus BAY-117082, exhibited the most intense inhibition of $N F-\kappa B$ transcriptional activity, compared to other experimental media or controls (Figure 4A, 4B). This finding was evidenced by the lowest negative ratios of relative NF$\kappa \mathrm{B}$ activity (with/without BAY 11-7082) (Figure 4A, 4B). In contrast, luciferase assay revealed that both HHPC and HHK exposed to bile at $\mathrm{pH} 7.0$ plus BAY-11-7082 demonstrated minor changes of $\mathrm{NF}-\kappa \mathrm{B}$ transcriptional activity compared to cells exposed to bile at $\mathrm{pH} 7.0$ without $\mathrm{NF}-\kappa \mathrm{B}$ inhibitor. This finding was represented by the highest negative ratios of relative $\mathrm{NF}-\kappa \mathrm{B}$ activity in HHPC and HHK exposed to bile at $\mathrm{pH}$ 7.0.

\section{BAY 11-7082 prevents the acidic bile-induced transcriptional levels of $\mathrm{NF}-\kappa \mathrm{B}$ and related genes with anti-apoptotic or oncogenic function in treated normal human hypopharyngeal cells}

We performed real time qPCR analysis on whole transcriptomes of acidic bile-treated normal human hypopharyngeal cell cultures exposed to BAY 11-7082. The acidic bile treated groups, without $\mathrm{NF}-\kappa \mathrm{B}$ inhibitor, demonstrated the highest transcriptional levels of the analyzed NF- $\kappa \mathrm{B}$ related genes with oncogenic function (Figures 5 and 6). Specifically, we observed that acidic bile groups without BAY 11-7082 produced a statistically significant difference compared to acid alone ( $\mathrm{pH} 4.0)$, bile at $\mathrm{pH} 7.0$ and neutral control (pH 7.0), in both HHPC
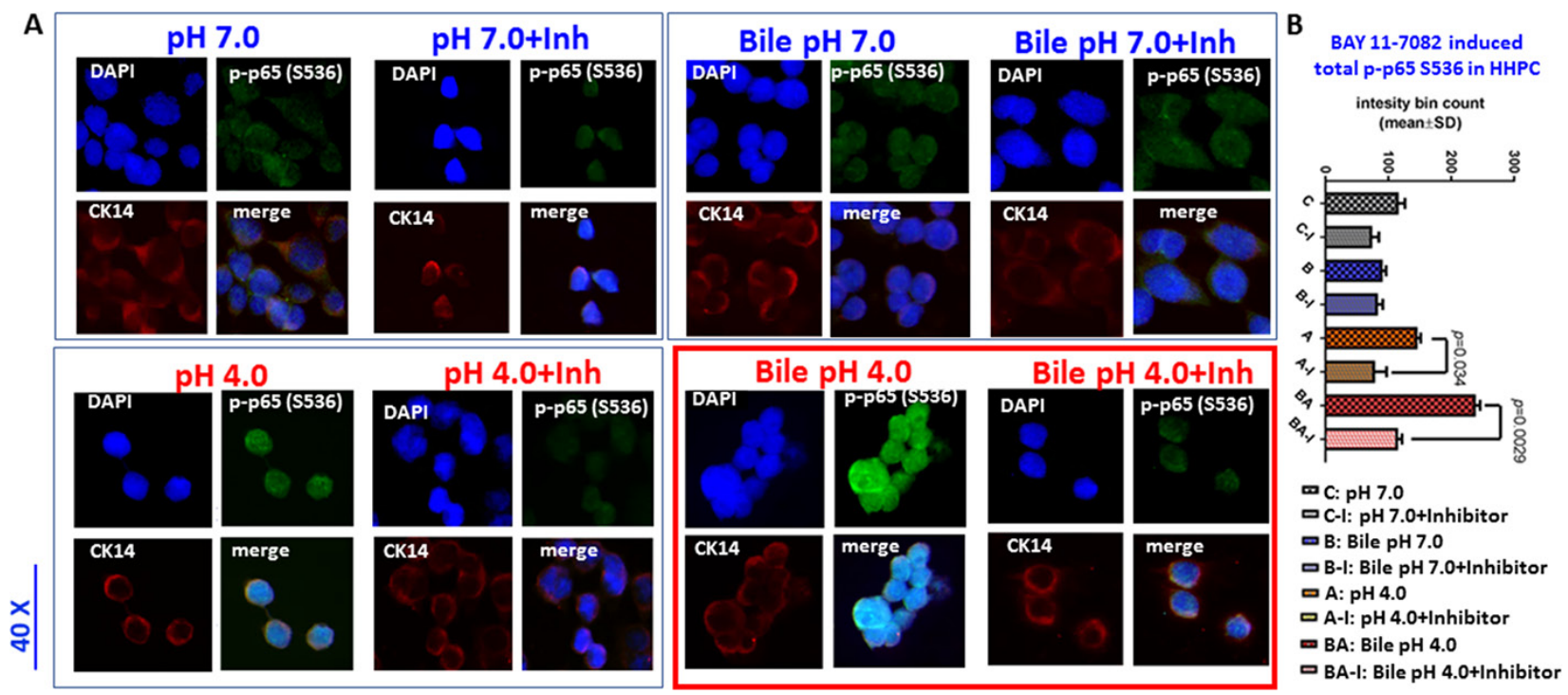

Figure 1: BAY 11-7082 inhibits the acidic bile-induced nuclear translocation of NF-кB (p65) phosphorylated at Ser536 in human primary hypopharyngeal cells. Immunofluorescence staining for phospho-NF- $\kappa B$ ( $p-p 65$ S536) reveals that application of BAY 11-7082 (A) decreases the nuclear translocation of p-p65 in acidic bile treated human hypopharyngeal primary cells (HHPC), demonstrating decreased p-p65 nuclear levels (green: p-p65 S536; red: CK14 for cytoplasmic staining; blue: DAPI for nuclear staining), and (B) significantly decreases total p-p65 (Ser536) levels, particularly in acid (pH 4.0) and acidic bile (pH 4.0) groups ( $p$ values by $t$-test; multiple comparisons by Holm-Sidak; GraphPad Prism 6.0). 
( $p=0.0106, p=0.0137$ and $p<0.0001$, respectively) and HHK $(p<0.0001, p=0.0007$ and $p=0.0005$, respectively), in line with our prior studies [21, 22] (by Friedman test; Dunns' multiple comparisons). BAY 117082 prevented bile-induced transcriptional activation of the analyzed genes at $\mathrm{pH} 4.0$, both in treated HHPC (Figure 5) and HHK (Figure 6). Specifically, we observed significantly lower transcriptional levels of the analyzed genes in HHPC and HHK treated with bile at $\mathrm{pH} 4.0$ plus BAY 11-7082, compared to those treated by acidic bile without inhibitor ( $p=0.0047$ and $p=0.0168$, respectively) (by Friedman test) (Figures 5A and 6A).

We found that BAY 11-7082 inhibited the acidic bile-induced overexpression of all the analyzed genes. However, RELA, STAT3, EGFR, bcl-2 and IL-1 $\beta$ were most affected genes by BAY 11-7082, in both acidic bile-treated HHPC and HHK (Figures $5 \mathrm{~B}$ and 6B). This was demonstrated by the strong differential expression of the analyzed genes with and without NF- $\kappa \mathrm{B}$ inhibitor ( $p$ values $<0.0001$; by $t$-test) (Figures 5 and 6 ; see Supplementary Tables 2 and 3). We also noticed that BAY 11-7082 reduced the c-REL mRNA levels both in neutral bile ( $\mathrm{pH} 7.0)$ and acidic bile ( $\mathrm{pH} 4.0)$ conditions, in HHPC (Figure 5B).

We performed multiple comparisons between the estimated ratios of relative transcriptional levels, with/ without NF- $\kappa \mathrm{B}$ inhibitor, in acidic bile-treated HHPC and $\mathrm{HHK}$, and control groups (Figure 7A and 7B). We observed that the acidic bile-treated group was the most affected by NF- $\kappa \mathrm{B}$ inhibitor. We showed that HHPC and HHK treated with bile at $\mathrm{pH} 4.0$ exhibited significantly lower mRNA ratios (with/without BAY 11-7082), compared to neutral-control $(p<0.00001$ and $p<0.0001$, respectively), bile at $\mathrm{pH} 7.0(p=0.0001$ and $p=0.0011$, respectively) and acid alone $(p=0.01$ and $p=0.0021$, respectively) (by Kruskal-Wallis).

Both HHK and HHPC exposed to vehicle (DMSO) resulted in similar mRNA levels to neutral-control (see Supplementary Figure 2 and Supplementary Table 4 online). We observed that only $\Delta \mathrm{Np} 63$ and IL-1 $\beta$ demonstrated significantly lower mRNA ratios in DMSOtreated HHK compared to control (Supplementary Figure 2B) $(t$-test, $p$ values $<0.05)$.

Figure 8 shows that NF- $\kappa \mathrm{B}$ inhibition downregulates the acidic bile-induced mRNA phenotype, including all analyzed genes. A less intense effect of NF$\kappa \mathrm{B}$ inhibition is observed in mRNA phenotypes of normal human hypopharyngeal cells treated by bile at $\mathrm{pH} 7.0$ and controls ( $\mathrm{pH} 7.0$ and $\mathrm{pH} 4.0$ ), suggesting that only a part of the analyzed genes is affected by BAY 11-7082.

\section{Correlations between BAY 11-7082 induced transcriptional levels of $\mathrm{NF}-\mathrm{K} B$ and related genes in HHK and HHPC}

We performed a Pearson analysis to determine correlations between the transcriptional levels of NF$\kappa \mathrm{B}$ transcriptional factor RELA(p65) and NF- $\kappa \mathrm{B}$ related genes in normal human hypopharyngeal cells exposed to $\mathrm{NF}-\kappa \mathrm{B}$ inhibitor (see Supplementary Figure 3 online). We found, in both treated HHK and HHPC, a significant linear correlation between BAY 11-7082 induced mRNAs of (i) RELA(p65) and TNF- $\alpha(r=0.926192$ and $r=0.921747$, respectively; $p<0.05$ ), as well as, (ii) RELA(p65) and
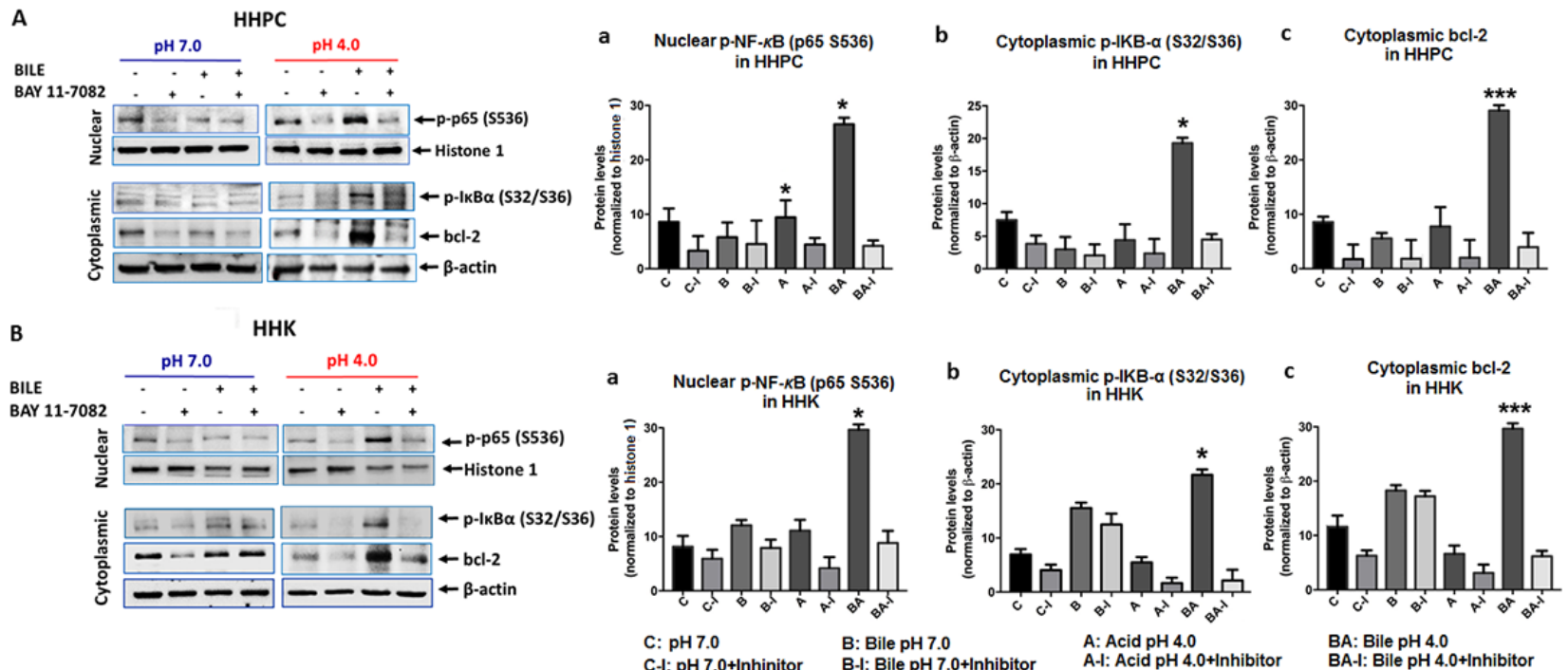

Figure 2: BAY 11-7082 inhibits the acidic bile-induced NF- $\kappa$ B activation and bcl-2 expression in normal human hypopharyngeal cells. Western blot analysis was performed in nuclear and cytoplasmic protein extracts of treated (A) human hypopharyngeal primary cells (HHPC) and (B) human hypopharyngeal keratinocytes (HHK) (with and without BAY 11-7082) for (a) p-NF$\kappa \mathrm{B}$ (p65 S536), (b) p-IкB- $\alpha$ (Ser32/36) and (c) bcl-2 (ONE-WAY ANOVA; Kruskal-Wallis, ${ }^{*} p<0.05 ;{ }^{* *} p<0.005 ;{ }^{* * *} p<0.0005$ GraphPad

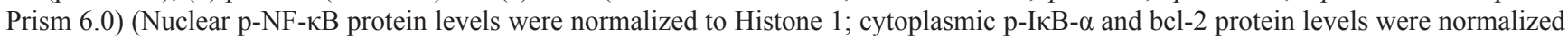
to $\beta$-actin. Data of three independent assays). 
$\Delta \mathrm{Np} 63$ genes $(r=0.915$ and $r=0.933285$, respectively; $p<0.05)$.

We also observed, in $\mathrm{HHK}$, a strong positive correlation between BAY 11-7082 induced mRNAs of (i) RELA(p65) and IL-1 $\beta(r=0.924554 ; p<0.05)$, (ii) RELA(p65) and IL-6 $(r=0.920726 ; p<0.05)$, (iii) $\operatorname{RELA}(\mathrm{p} 65)$ and STAT3 $(r=923810772, \mathrm{p}<0.5)$, and (iv) RELA(p65) and bcl-2 $(r=0.92646569, p<0.05)$.

We performed a Pearson analysis between BAY 11-7082 induced mRNA levels of the NF- $\kappa B$ related cytokines, IL-1 $\beta$ and IL- 6 , and each of the analyzed NF$\kappa \mathrm{B}$ related genes in treated cells (see Supplementary Figure 4 online). In HHK, we observed a strong linear correlation between (i) IL- $1 \beta$ and TNF- $\alpha$ ( $r=0.992982 ; p$ $<0.05)$, (ii) IL-6 and TNF- $\alpha(r=0.998645 ; p<0.05)$, and (iii) IL-1 $\beta$ and $\Delta \operatorname{Np} 63(r=0.999548 ; p<0.05)$. Similarly, in HHK, we observed a strong linear correlation between (i) IL-6 and $\Delta \operatorname{Np} 63(r=0.998349 ; p<0.05)$, (ii) IL-1 $\beta$ and STAT3 $(r=0.992072, p<0.05)$, and (iii) IL-6 and STAT3 $(r=0.998183, p<0.05)$. Finally, in HHK, we again showed a significant linear correlation between (i) IL-1 $\beta$ and WNT5A $(r=0.993047, p<0.05)$, (ii) IL-6 and
WNT5A ( $r=0.998653, p<0.05)$, as well as between (iii) IL-1 $\beta$ and IL-6 $(r=0.9997677574, p<0.5)$.

\section{BAY 11-7082 reduced acidic bile-induced} gene expression profiling for $\mathrm{NF}-\kappa \mathrm{B}$ signaling pathway in normal human hypopharyngeal cells

Our findings from qPCR analysis demonstrated that BAY 11-7082 induced the most significant reduction of activated NF- $\kappa \mathrm{B}$ and related genes in the acidic biletreated groups. Therefore, we performed a PCR array for the NF- $\kappa \mathrm{B}$ signaling pathway to explore acidic bileinduced gene expression profiling of NF- $\kappa \mathrm{B}$ signaling inhibition by BAY 11-7082. The results of the PCR array demonstrated that BAY 11-7082 reduced the acidic bileinduced transcriptional levels of 72 out of 84 analyzed NF-кB-related genes ( 85\%) ( $>2$-fold change) (Table 1).

The effect of BAY 11-7082 on the NF- $\kappa$ B pathway and its genes is provided in Figure 9. NF- $\kappa \mathrm{B}$ inhibitor reduced the mRNA levels of the $\mathrm{NF}-\kappa \mathrm{B}$ transcription factors, RELA(p65) (13-fold), RELB (> 6-fold), and NFkB1 $(>1,000$-fold), NFkB2 (>130-fold), as well as
A a Nuclear p-p65 (S536) with/without BAY11-7082 in HHPC
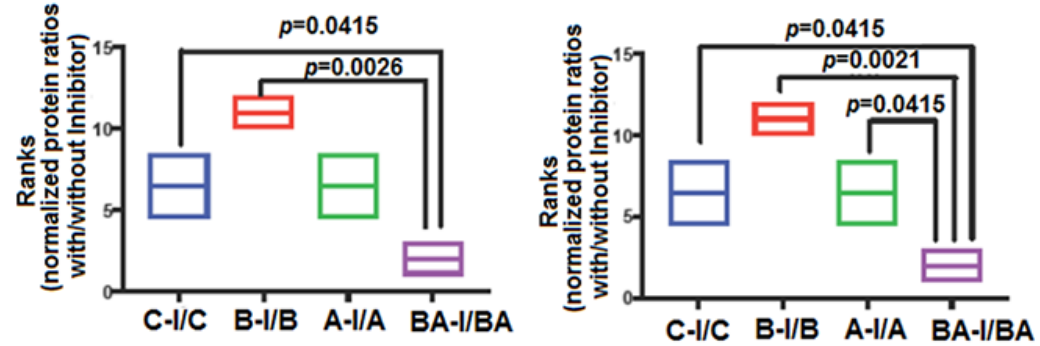

plasmic p-IKB-a with/with
BAY 11-7082 in HHPC

\section{Cytoplasmic bcl-2 with/without BAY 11-7082 in HHPC}

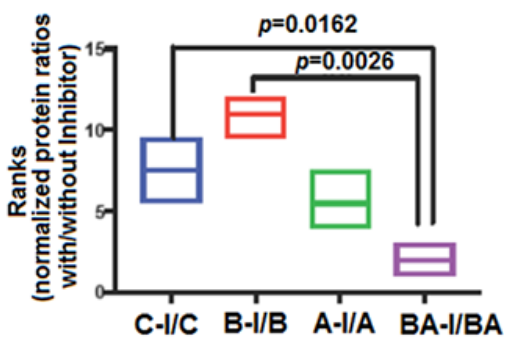

B

a Nuclear p-p65 (\$536) with/without BAY11-7082 in HHK
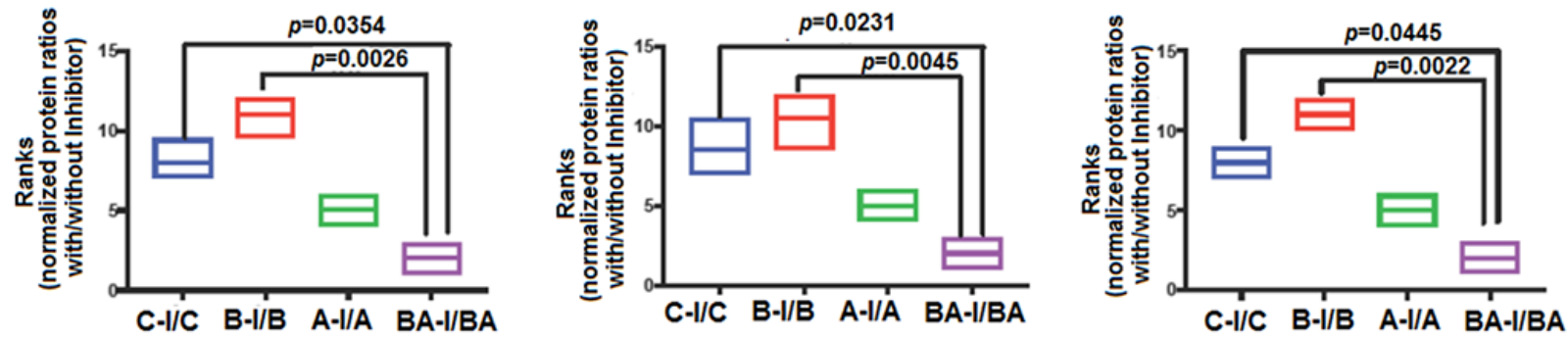

A-I/A: Acid pH 4.0 with/without Inhibitor

BA-I/BA: Bile pH 4.0 with/without Inhibitor

Figure 3: Acidic bile (pH 4.0) treated normal human hypopharyngeal cells demonstrate the most significant reduction of activated NF- $\kappa$ B, p-IкB- $\alpha$ and bcl-2 protein levels in the presence of BAY 11-7082. (A) Human hypopharyngeal primary cells (HHPC), and (B) Human hypopharyngeal keratinocytes (HHK). Graphs created by Graph Pad Prism 6.0 software reveal ranks of (a)

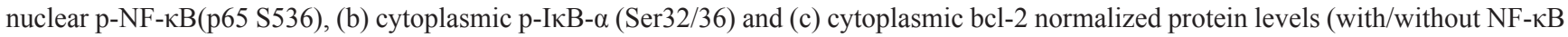
inhibitor) between different experimental and control groups, in treated HHPC and HHK, by western blot analysis. (ONE-WAY ANOVA; Kruskal-Wallis; GraphPad Prism 6.0). (Nuclear p-NF-кB protein levels were normalized to Histone 1; cytoplasmic p-IкB- $\alpha$ and bcl-2 protein levels were normalized to $\beta$-actin. Data of of three independent experiments). 
members of TNF-receptors, such as CD27(TNFRS7) (> 22-fold), TNFRSF10A ( $>$ 100-fold), TNFRSF10B ( $>$ 50-fold), TNFRSF1A ( $>$ 12-fold), TNFSF10 ( $>10$-fold) and TNFSF14 (>14-flod), TLR1 ( $>$ 50-fold), TLR-2 $(>$ 90-fold), TLR4 (>15-fold) TLR6 (>1,000-fold), as well as IL10 and IL1A (> 16-fold) and others. BAY 11-7082 also reduced NF- $\mathrm{B}$ downstream signaling, preventing the expression of positive regulators of the NF- $\kappa \mathrm{B}$ pathway, such as BIRC2 (> 5-fold), IRAK1 and IRAK $2(>15$ fold), IRF1 ( $>$ 250-fold), MYD88 ( $>$ 8-fold), TBK1 ( $>$ 19-fold), TRAF2, TRAF3 and TRAF6 (> 30-fold). The effect of BAY 11-7082 also reduced the expression of Inhibitor-kappaB kinases, CHUK (IKKa) (> 290-fold), and IKBKB, IKBE and IKBKG (>16-fold), inhibiting the cytoplasmic release of NF- $\kappa \mathrm{B}$. On the other hand, BAY 11-7082 induced the expression of NFKBIA ( $>3$-fold) and NFKBIB ( $>26$-fold), keeping NF- $\kappa$ B protein complexes sequestered in an inactive state in the cytoplasm.

$N F-\kappa B$ inhibition resulted in reduction of $N F-\kappa B$ responsive genes in acidic bile treated cells. Specifically, we observed a reduction in the expression of genes, such as kinase MAP3K1 ( $>220$-fold), and transcriptional factors, such as ATF1 ( $>$ 10-fold), EGR1 ( $>$ 7-fold), ELK1 ( $>$ 16-fold), FOS (>1,000-fold) and STAT1 ( $>20$-fold). Finally, we found a high level of reduction in BCL10 ( $>$ 250 -fold) and CARD11 (>28-fold), activators of NF- $\kappa$ B through BCL10.

\section{DISCUSSION}

Although there is a heterogeneity of molecular profiles in head and neck cancer, Cheng and Van Waes have strongly suggested the central role of Nuclear Factor kappaB in a subset of Head and Neck Squamous Cell Carcinoma (HNCC) $[31,32] . \mathrm{NF}-\kappa \mathrm{B}$ is a fundamental mediator between inflammation and cancer and its possible role as a mechanistic link between chronic inflammatory events and activation of oncogenic pathways is well recognized $[33,34]$. Additionally, inhibition of NF$\kappa \mathrm{B}$ has been recently shown to be inversely related to head and neck tumor progression and invasion [35] promising its use in cancer prevention and therapy [27].

Despite the known risks of tobacco and alcohol consumption in head and neck carcinogenesis, there is an increasing clinical correlation between laryngopharyngeal reflux or LPR and laryngopharyngeal neoplasia [4-6, 36, 37]. Prior findings from our in vitro and in vivo models demonstrated that acidic bile can induce NF- $\kappa$ B activation and accelerate the transcriptional levels of genes related to oncogenic function $[21,22]$. We previously have shown that bile and acid in combination contributed significantly to $\mathrm{NF}-\kappa \mathrm{B}$ activation and bcl-2 overexpression in vitro, in treated normal hypopharyngeal cells, and in vivo, in murine hypopharyngeal mucosa, relative to acid alone or other factors such as topical glucose or pepsin [21-
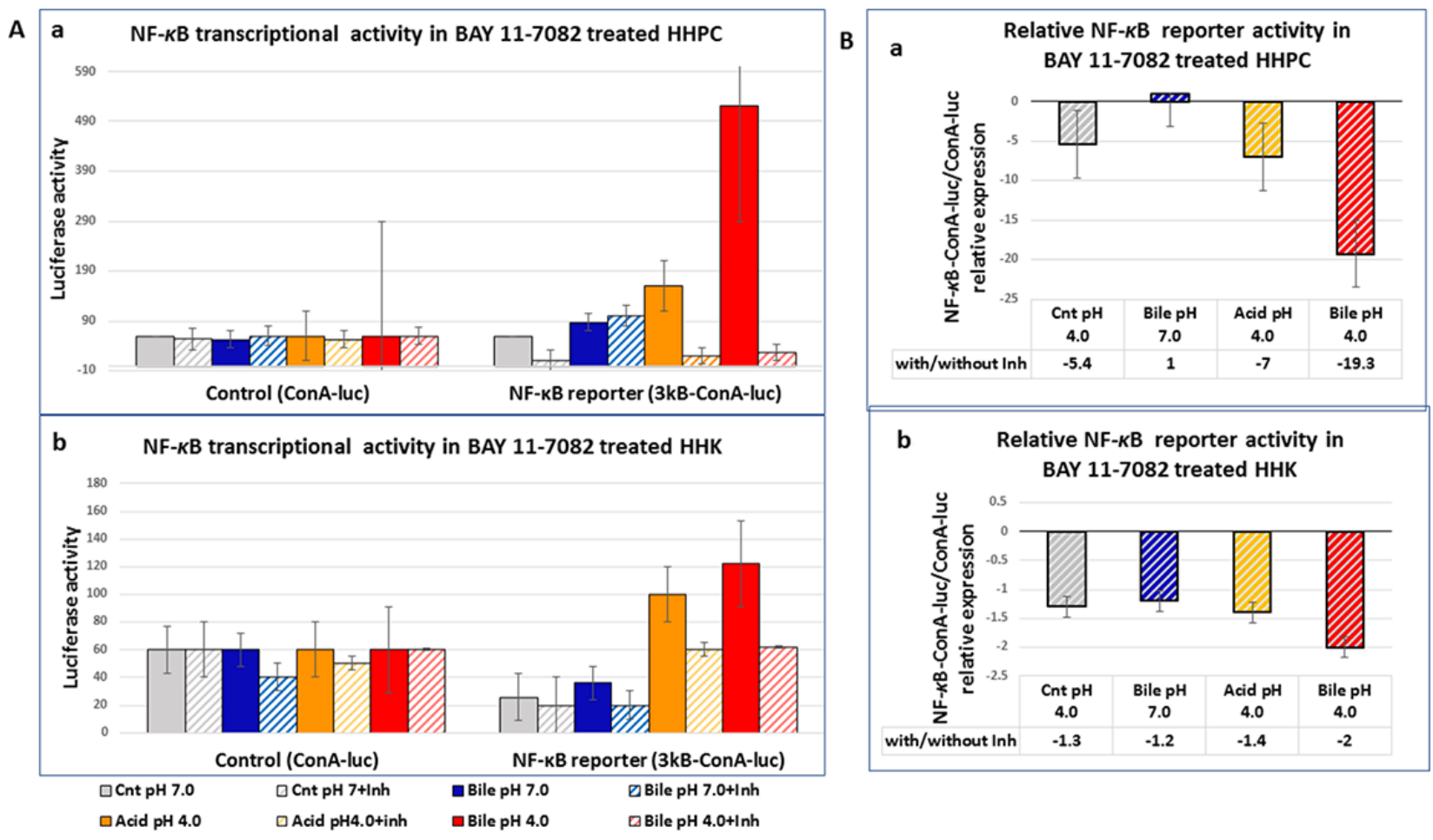

Figure 4: BAY 11-7082 suppresses NF- $\kappa$ B transcriptional activity in HHPC and HHK treated by acidic bile. (A) Graphs depict the luciferase activity (mean $\pm \mathrm{SD}$ of two independent experiments) in (a) HHPC and (b) in HHK transfected with control (conA-luc) or NF- $\kappa$ B responsive (3kB-conA-luc) luciferase reporter. (B) Graphs depict the NF- $\kappa$ B relative (3kB-conA-luc/conA-luc) transcriptional activity levels, in (a) HHPC and (b) HHK, showing that BAY 11-7082 suppresses NF- $\mathrm{kB}$ transcriptional activity in treated cells, particularly in the acidic bile-treated groups. 
Table 1: Down-regulation of NF-кB signaling pathway in acidic bile with BAY 11-7082 treated normal human hypopharyngeal cells

\begin{tabular}{|c|c|c|c|c|c|}
\hline Gene & "Fold regulation & Gene & Fold regulation & Gene & Fold regulation \\
\hline AGT & -16.1537 & HMOX1 & -28.5629 & RAF1 & -1.9048 \\
\hline AKT1 & -18.3971 & ICAM1 & -16.1537 & REL & -30.4768 \\
\hline ATF1 & -10.5717 & IFNA1 & -20.6671 & RELA & -13.0886 \\
\hline BCL10 & -258.858 & IFNG & 30.6027 & RELB & -6.6377 \\
\hline BCL2A1 & -31.7151 & IKBKB & -192.093 & RHOA & 11.7111 \\
\hline BCL2L1 & -23.4387 & IKBKE & -16.1537 & RIPK1 & -16.1537 \\
\hline BCL3 & -33.8756 & IKBKG & -16.1537 & STAT1 & -22.2708 \\
\hline BIRC2 & -5.1434 & IL10 & -16.1537 & TBK1 & -19.7758 \\
\hline BIRC3 & -11.5315 & IL1A & -16.1537 & TICAM1 & -16.5324 \\
\hline CARD11 & -28.861 & IL1B & -49.4878 & TICAM2 & -16.1537 \\
\hline CASP1 & -807.1 & IL1R1 & -34.9508 & TIMP1 & -230.741 \\
\hline CASP8 & -807.1 & CXCL8 & -29.7664 & TLR1 & -59.8221 \\
\hline CCL2 & -16.1537 & IRAK1 & -16.1537 & TLR2 & -94.5984 \\
\hline CCL5 & -1.5542 & IRAK2 & -15.0469 & TLR3 & -1.5561 \\
\hline $\mathrm{CD} 27$ & -22.2086 & IRF1 & -250.692 & TLR4 & -15.56 \\
\hline $\mathrm{CD} 40$ & -1.1076 & JUN & -250.692 & TLR6 & -4802.17 \\
\hline CFLAR & -19.0453 & LTA & -16.1537 & TLR9 & -1.3347 \\
\hline CHUK & -293.394 & LTBR & 4.039 & TNF & -1366.74 \\
\hline CSF1 & -472.978 & MALT1 & -46.6225 & TNFAIP3 & -54.5169 \\
\hline CSF2 & -11.1574 & MAP3K1 & -227.97 & TNFRSF10A & -109.034 \\
\hline CSF3 & -22.3147 & MYD88 & -8.1661 & TNFRSF10B & -51.1432 \\
\hline EGFR & -7.6029 & NFKB1 & -2723.64 & TNFRSF1A & -12.1615 \\
\hline EGR1 & -7.6029 & NFKB2 & -131.744 & TNFSF10 & -10.3132 \\
\hline ELK1 & -16.1537 & NFKBIA & 3.3532 & TNFSF14 & -16.1537 \\
\hline F2R & -12.5571 & NFKBIB & 26.0694 & TRADD & -34.034 \\
\hline FADD & -25.1141 & NFKBIE & -22.2708 & TRAF2 & -42.32 \\
\hline FASLG & 4.8938 & NOD1 & 20.0837 & TRAF3 & -174.151 \\
\hline FOS & -1073.93 & PSIP1 & -50.9866 & TRAF6 & -31.2479 \\
\hline
\end{tabular}

"Up-Down Regulation in acidic bile with BAY 11-7082 (group 1), comparing to acidic bile without BAY 11-7082 treated normal human hypopharyngeal cells (control group).

23]. We showed in vivo that this combination induced premalignant hypopharyngeal lesions, exhibiting increased cell proliferation rates and transcriptional activation of genes with anti-apoptotic or oncogenic function, such as EGFR, STAT3, TNF- $\alpha$, wnt5A. The negative or reduced effect of acid alone and/or bile at neutral $\mathrm{pH}$, compared to acidic bile salts showed that the latter may be especially injurious. Here, we explored the inhibition of NF- $\mathrm{kB}$ in preventing the acidic bile-induced mRNA phenotype, including previously analyzed NF- $\mathrm{KB}$ transcriptional factors, such as RELA(p65) and c-REL, anti-apoptotic or oncogenic factors, bcl-2, EGFR, STAT3, and $\Delta$ Np63, cell signaling factor TNF- $\alpha$, NF- $\kappa$ B related cytokines IL- $1 \beta$ and IL-6, and epithelial mesenchymal transition (EMT) mediator WNT5A. We further explored the effect of BAY 11-7082 on the inhibition of the acidic bile-induced transcriptional activation of NF- $\kappa B$ signaling pathway.

Our novel findings demonstrate that NF- $\kappa B$ inhibition, by BAY 11-7082, effectively prevents the acidic bile-induced overexpression of the analyzed genes, in treated normal human hypopharyngeal cells. BAY 11-7082 effectively reduced the acidic bile-induced expression of 72 genes related to NF- $\kappa \mathrm{B}$ signaling pathway. These findings strongly support our hypothesis that the acidic bile-induced mRNA phenotype is mainly produced by NF$\kappa \mathrm{B}$-related signaling pathways and that NF- $\mathrm{KB}$ may be a critical link between acidic bile and preneoplastic events in our model. 
TNF- $\alpha$ is a major inflammatory cytokine with a key role in cancer $[15,38]$, and with NF- $\kappa B$ central to its activation in HNSCC [17]. Previous studies demonstrate that NF- $\kappa \mathrm{B}$ is capable of directly or indirectly activating oncogenic pathways via cytokines, such as IL-6 and IL-1 $\beta$, in HNSCC $[13,18]$. Our data demonstrate that $\mathrm{NF}-\kappa \mathrm{B}$ inhibition can block the acidic bile-induced overexpression of $\mathrm{TNF}-\alpha, \mathrm{NF}-\kappa \mathrm{B}$ transcriptional factor RELA(p65), and cancer related cytokines, IL-1 $\beta$ and IL6. Our analysis reveals a strong association between BAY 11-7082-induced transcriptional levels of RELA(p65) and TNF- $\alpha$ or the analyzed cytokines. We believe these observations suggest that NF- $\kappa \mathrm{B}$ inhibition is capable of blocking acidic bile-induced downstream pathways that link inflammation to cancer.

The anti-apoptotic role of $\mathrm{NF}-\kappa \mathrm{B}[35,39]$, as well as interactions of $\mathrm{NF}-\kappa \mathrm{B}$ with oncogenic factors, such as EGFR and STAT3 have been previously cited in HNSCC $[11,39,40]$. STAT3 is an important factor with oncogenic function in head and neck malignancies [13].
EGFR is also broadly expressed in head and neck cancer and has been linked to patient survival $[11,13]$. Our data demonstrate that BAY 11-7082 effectively prevents the acidic bile-induced overexpression of anti-apoptotic bcl2, and oncogenic EGFR and STAT3, in normal human hypopharyngeal cells. These observations strongly support the role of BAY 11-7082 in effectively diminishing the proposed oncogenic effect of acidic bile.

c-REL is an important member of NF- $\kappa B$ family and acts as an oncoprotein in HNSCC through interactions with $\Delta N p 63$, via the TNF- $\alpha$ pathway [41]. Yang et al. reveal that $\triangle \mathrm{Np} 63$ is a master transcription factor that in coordination with $\mathrm{NF}-\kappa \mathrm{B} / \mathrm{RELs}$, promotes inflammation and the malignant phenotype of HNSCC [42]. Our current data show that NF- $\kappa$ B Inhibition significantly prevents c-REL expression, particularly in human hyopharyngeal cells exposed to bile at $\mathrm{pH}$ 4.0. We also show that inhibition of NF- $\kappa \mathrm{B}$ reduces $\Delta \mathrm{Np} 63$ transcriptional levels, while BAY 11-7082-induced RELA(p65) and $\Delta \mathrm{Np} 63$ mRNA levels demonstrate a strong linear correlation.
A
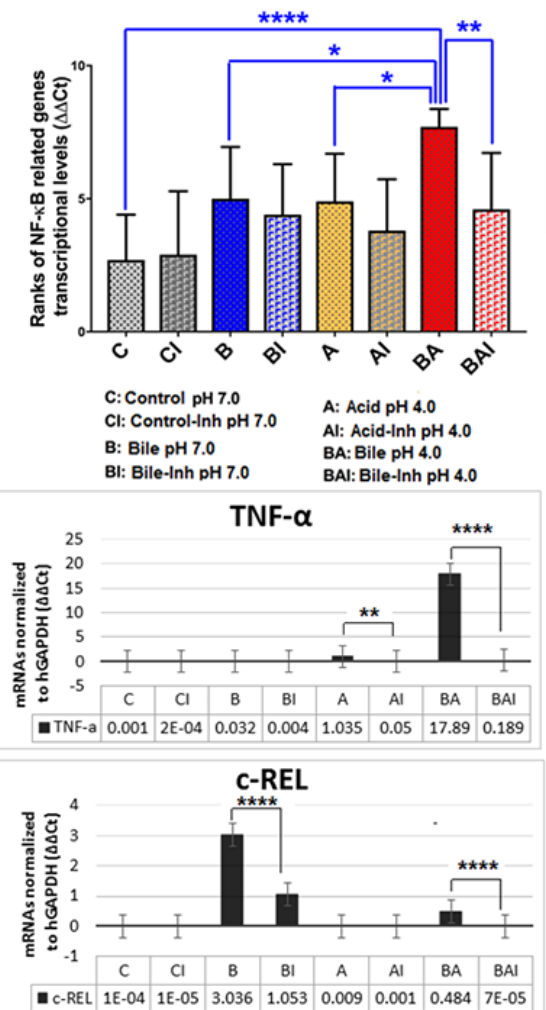

B

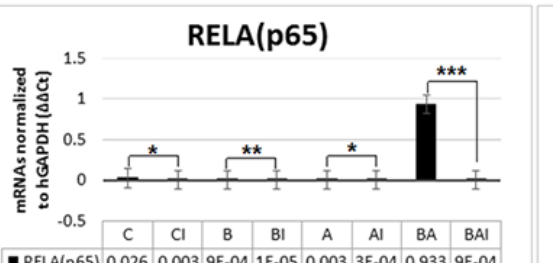

$\begin{array}{llllllllllll}\text { - RELA(p65) } & 0.026 & 0.003 & 9 E-04 & 1 E-05 & 0.003 & 3 E-04 & 0.933 & 9 E-04\end{array}$
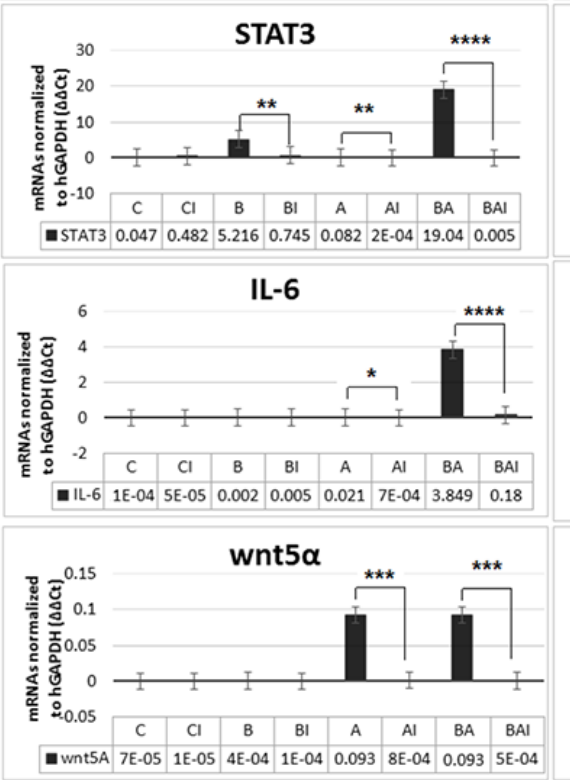

bcl-2

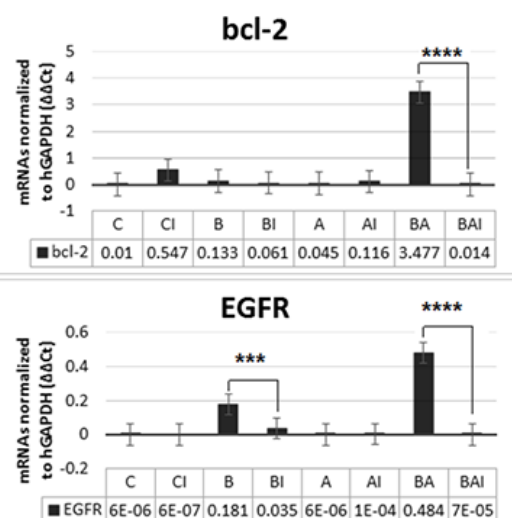
- EGFR 6E-06 $6 E-070.1810 .035$ 6E-06 1 1E-04 0.484 7E-05

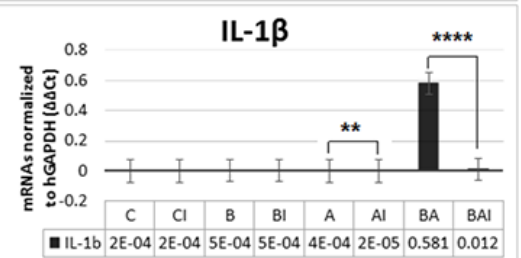

\begin{tabular}{llllllllll}
\hline - IL-1b & $2 E-04$ & $2 E-04$ & $5 E-04$ & $5 E-04$ & $4 E-04$ & $2 E-05$ & 0.581 & 0.012 \\
\hline
\end{tabular}

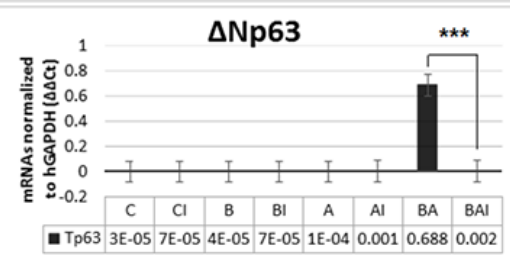

Figure 5: Inhibition of NF- $\kappa$ B prevents the acidic bile-induced overexpression of genes with oncogenic function in treated human hypopharyngeal primary cells (HHPC). NF- $\kappa \mathrm{B}$ inhibition-induced transcriptional levels (with and without BAY 11-7082) of the analyzed NF- $\mathrm{kB}$ related genes with oncogenic function, are depicted for bile-treated human hypopharyngeal primary cells (HHPC). The data are derived by real time qPCR analysis. (A) Graphs, created by Graph Pad Prism 6 software, reveal transcriptional levels (normalized to $h \mathrm{GAPDH}$ ) for the analyzed genes between different experimental and control groups of treated HHPC (ONE-WAY ANOVA, Freidman test; ${ }^{*} p<0.05 ;{ }^{* *} p<0.005$ ). (B) Graphs represent transcriptional levels of each analyzed gene, bcl-2, EGFR, $\Delta$ Np63, c-REL, RELA(p65), TNF- $\alpha$, STAT3, WNT5 $\alpha$, IL-6 and IL-1 $\beta$ (relative to hGAPDH reference gene), in HHPC treated with and without BAY 11-7082 $\left({ }^{*} p<0.05 ;{ }^{* *} p<0.005,{ }^{* * *} p<0.0005,{ }^{* * * *} p<0.00005\right.$, by $t$-test; multiple comparisons by Holm-Sidak; GraphPad Prism 6.0). (Data of three independent experiments). 
These findings further demonstrate that NF- $\kappa \mathrm{B}$ inhibition can affect acidic bile-induced inflammatory and cell proliferation signaling pathways.

WNT5A, linked to the epithelial mesenchymal transition (EMT) process and cancer progression [43], has been shown to be upregulated by NF- $\kappa \mathrm{B}$ signaling [44]. Furthermore, our prior in vivo model showed that acidic bile is capable of altering both the expression of WNT5A and the cell-cell adhesion molecules, $\beta$-catenin and E-Cadherin [22]. This interaction was observed in treated murine laryngopharyngeal mucosa that exhibited premalignant changes with strong NF- $\kappa \mathrm{B}$ activation [22]. Here our data show that NF- $\kappa \mathrm{B}$ inhibition suppresses the acidic bile-induced overexpression of WNT5, in treated cells, supporting the possibility that inhibition of NF- $\kappa \mathrm{B}$ may offer protection from changes associated with cellcell interactions.

Finally, our data show a strong positive correlation between BAY 11-7082-induced transcriptional levels of RELA(p65) and oncogenic STAT3 or WNT5A, confirming previously suggested interactions among these factors, in acidic bile-treated normal human hypopharyngeal cells [21].

\section{MATERIALS AND METHODS}

\section{Normal human hypopharyngeal keratinocyte cultures}

We used human hypopharyngeal primary cells (HHPC) from Celprogen Inc. CA, USA. The HHPC were plated in non-coated flasks and were grown in Human Hypopharyngeal Normal Cell Culture Media with Serum (Celprogen Inc. CA, USA), at $37^{\circ} \mathrm{C}$ in humidified air and $5 \%$ CO2. The HHPC were sub-cultured and media were gradually replaced by Serum Free Media (Celprogen Inc. CA, USA), and passed after reaching $\sim 90 \%$ confluence, using $0.05 \%$ trypsin-EDTA (Gibco ${ }^{\circledR}$, NY, USA).

We also established a telomerase-immortalized human hypopharyngeal keratinocytes (HHK), by expression

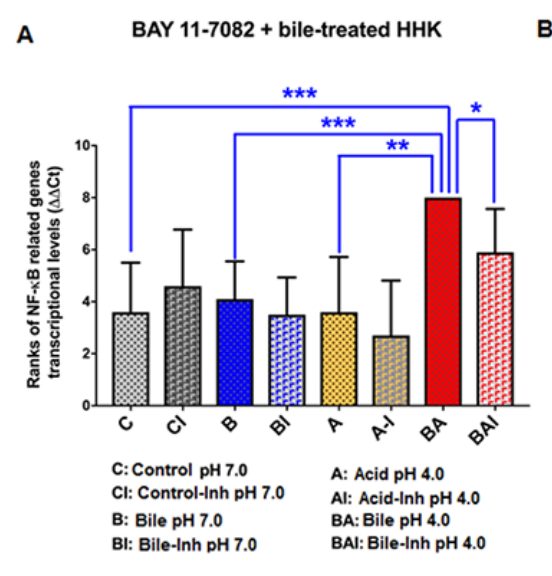

B

BAY 11-7082-induced mRNA levels in HHK
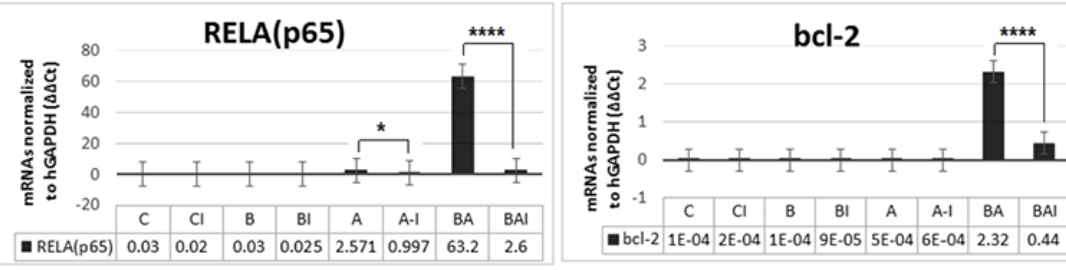

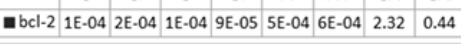
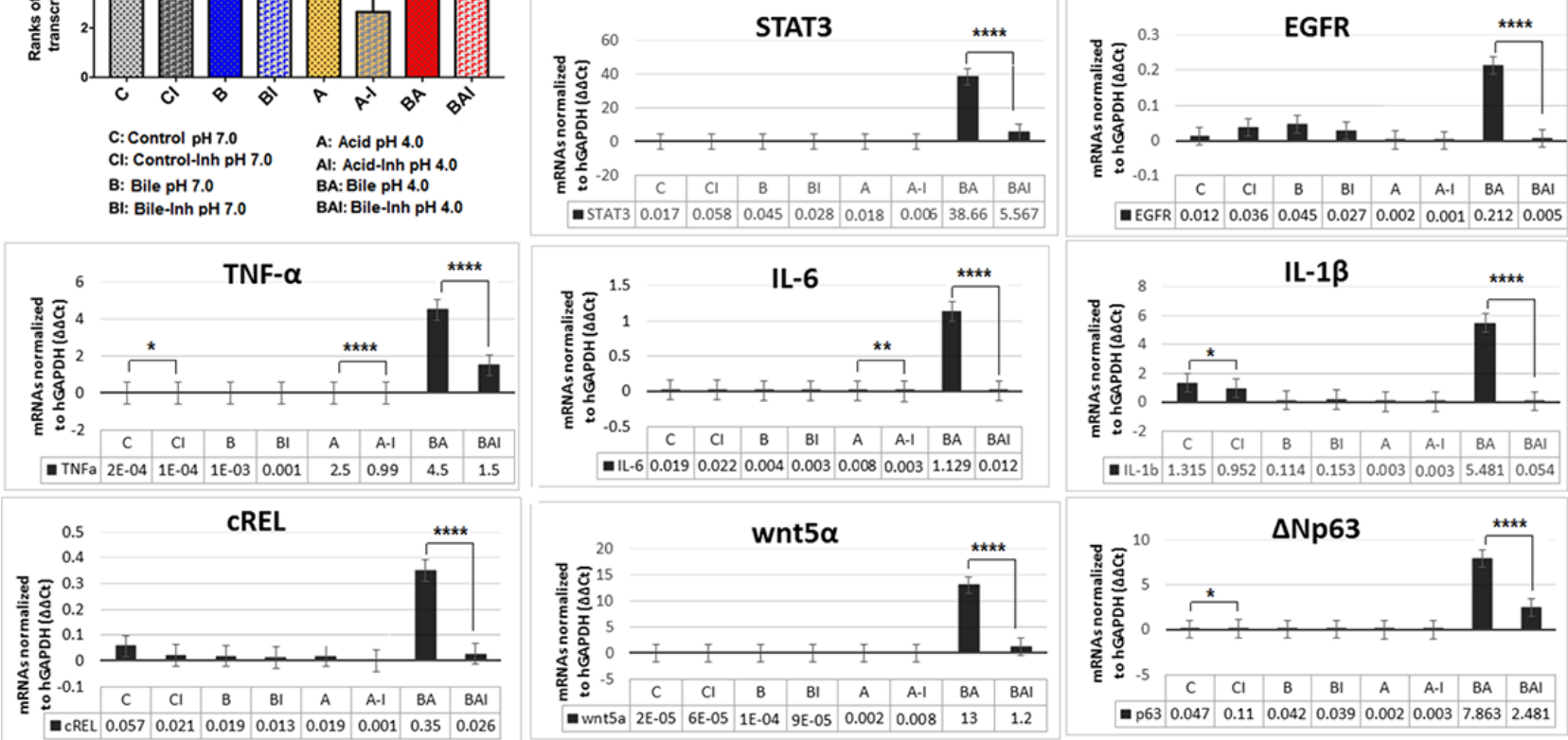

Figure 6: Inhibition of NF- $\kappa \mathrm{B}$ prevents the acidic bile-induced overexpression of genes with oncogenic function in treated human hypopharyngeal keratinocytes (HHK). NF- $\mathrm{KB}$ inhibition-induced transcriptional levels (with and without BAY 11-7082) of the analyzed NF- $\mathrm{kB}$ related genes with oncogenic function, are depicted for bile-treated human hypopharyngeal keratinocytes (HHK). The data are derived by real time qPCR analysis. (A) Graphs, created by Graph Pad Prism 6 software, reveal transcriptional levels (normalized to $h \mathrm{GAPDH}$ ) for the analyzed genes between different experimental and control groups of treated HHK (ONE-WAY ANOVA, Freidman test; ${ }^{*} p<0.05 ;{ }^{* *} p<0.005$ ). (B) Graphs represent transcriptional levels of each analyzed gene, bcl-2, EGFR, $\triangle$ Np63, c-REL, RELA(p65), TNF- $\alpha$, STAT3, WNT5 $\alpha$, IL-6 and IL-1 $\beta$ (relative to hGAPDH reference gene), in HHK treated with and without BAY 11$7082\left({ }^{*} p<0.05 ;{ }^{* *} p<0.005,{ }^{* * *} p<0.0005,{ }^{* * * *} p<0.00005\right.$, by $t$-test; multiple comparisons by Holm-Sidak; GraphPad Prism 6.0). (Data of three independent experiments). 
of hTERT, extending its life span without altering the characteristic phenotypic properties of the cells, as previously described [20]. HHK, were grown in keratinocyte serum free basal medium (KGM-2 SF, Gibco ${ }^{\circledR}$, NY, USA) supplemented by L-Glutamine, BPE, hEGF and gentamicin $\left(\mathrm{Gibco}^{\circledR}, \mathrm{NY}\right.$, USA), at $37^{\circ} \mathrm{C}$ in humidified air and $5 \% \mathrm{CO} 2$.

\section{Treatment conditions}

Bile-treatment: HHPC (2nd passage) and the HHK (4th passage) underwent a repetitive exposure to experimental and control media for 10-15 min, 3 times per day, for 5 days, as previously described [21]. Experiments were performed in triplicate for each cell line. In each assay HHPC and HHK were treated after 2nd and 4th passage, respectively.

Experimental groups included a repetitive exposure to bile at $\mathrm{pH} 4.0$, the cut off of reflux disease [45], and at $\mathrm{pH} \mathrm{7.0,} \mathrm{as} \mathrm{follows:} \mathrm{(a)} \mathrm{bile} \mathrm{at} \mathrm{pH}$ 4.0, containing $400 \mu \mathrm{M}$ of conjugated bile salts mixture $(\mathrm{GCA}+\mathrm{TCA}+\mathrm{GCDCA}+\mathrm{TCDCA}+\mathrm{GDCA}+\mathrm{TDCA}$, Sigma, St. Louis, MO and Calbiochem, San Diego, CA; USA) at molar concentration $(20: 3: 15: 3: 6: 1)$ as previously described [21], in full growth medium (Dulbecco modified Eagle's medium/F12 10\% FBS, 1\% pen/strep, Gibco ${ }^{\circledR}$, NY, USA), brought to a $\mathrm{pH}$ of 4.0 with $1 \mathrm{M} \mathrm{HCl}$ (using a $\mathrm{pH}$ meter) and (b) bile at $\mathrm{pH} 7.0$, containing the same bile salts mixture in DMEM/F12 10\% FBS, at pH 7.0.

A
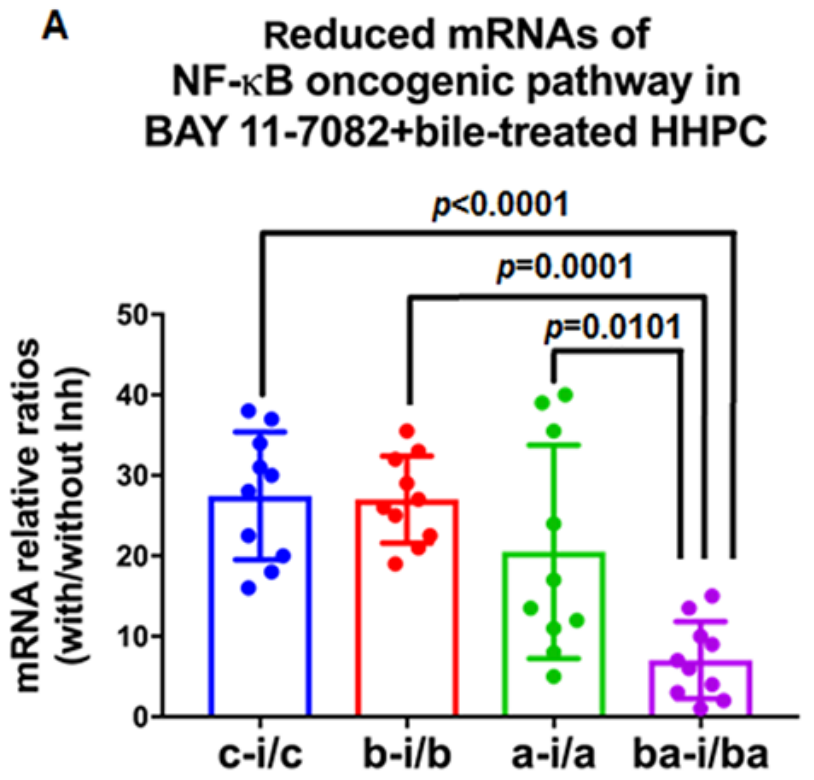

c-i/c: pH 7.0 with/without Inh b-i/b: Bile pH 7.0 with/without Inh
Control groups included a repetitive exposure to acid alone $(\mathrm{pH} 4.0)$ considered a positive control and neutral fluid $(\mathrm{pH} 7.0)$ considered a reference control, as follows: (a) Acid control, full growth DMEM/F12 10\% FBS, brought to $\mathrm{pH} 4.0$ with $1 \mathrm{M} \mathrm{HCl}$, and (b) neutral control, full growth DMEM/F12 10\% FBS, pH 7.0. The media were removed and replaced with serum free media until the next exposure cycle [Human Hypopharyngeal Normal Cell Culture Media Serum Free, for HHPC cells; (Celprogen Inc. CA, USA), and KGM-2 SF, for HHK cells $\left.\left(\mathrm{Gibco}^{\circledR}, \mathrm{NY}, \mathrm{USA}\right)\right]$.

BAY-11-7082 treatment: HHPC and HHK underwent an additional procedure of combined repetitive exposure to bile with BAY-11-7082, a pharmacologic inhibitor of NF- $\kappa \mathrm{B}$ (Calbiochem (C) 2016 EMD Millipore Corporation; Germany), for 10-15 min, 3 times per day, for 5 days.

Experimental groups included an identical procedure of repetitive exposures of HHPC and HHK to bile at $\mathrm{pH}$ 4.0 or $\mathrm{pH} 7.0$, as described above, in combination with BAY 11-7082, as follows: (a) bile at $\mathrm{pH} 4.0$, containing $400 \mu \mathrm{M}$ of conjugated bile mixture plus $10 \mu \mathrm{M}$ of BAY 11-7082, in full growth medium, at $\mathrm{pH} 4.0$ and (b) bile at pH 7.0 plus BAY 11-7082, containing the same bile salts and NF- $\mathrm{B}$ inhibitor mixture, in full growth medium, at $\mathrm{pH}$ 7.0. We selected a concentration of $10 \mu \mathrm{M}$ of BAY 117082 in accordance with previous reports [46].

Control groups included repetitive exposure to acid alone ( $\mathrm{pH} 4.0)$ and neutral fluid $(\mathrm{pH} 7.0)$ in combination

\section{B Reduced mRNAs of NF-KB oncogenic pathway in BAY 11-7082+bile-treated HHK}

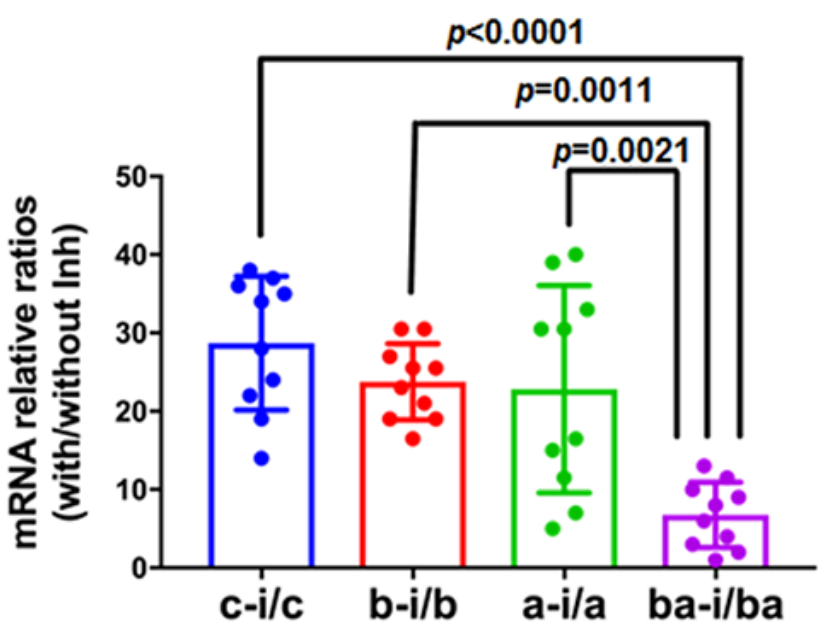

a-i/a: pH 4.0 with/without Inh ba-il/ba: Bile pH 4.0 with/without Inh

Figure 7: Acidic bile-treated groups in the presence of BAY 11-7082 produced the most significant mRNA reduction of NF- $\kappa$ B related genes with oncogenic function in treated normal human hypopharyngeal cells. Graphs created by Graph Pad Prism 6.0 software reveal ranks of transcriptional levels (with/without NF- $\kappa$ B inhibitor) of NF- $\kappa$ B related genes with oncogenic function between different experimental and control groups, in treated (A) human hypopharyngeal primary cells (HHPC) and (B) human hypopharyngeal keratinocytes (HHK), by real time qPCR. (ONE-WAY ANOVA, Kruskal-Wallis). 
with BAY 11-7082, as follows: (a) Acid control, full growth medium, as described above, plus $10 \mu \mathrm{M}$ of BAY 117082 , at $\mathrm{pH} 4.0$ that was used as positive control and (b) neutral control, full growth medium, as described above, plus $10 \mu \mathrm{M}$ of BAY 11-7082, at pH 7.0. We also included additional control groups of untreated cells, used as negative control and groups of cells repetitively exposed to DMSO, at concentrations similar to those used for BAY 11-7082 solubilisation used as reference control for the NF- $\kappa$ B inhibitor vehicle. Cells of experimental and control groups that were treated without inhibitor did not include a vehicle control. The media were removed and replaced with serum free media until the next exposure cycle, as described above.

Procedures on both cell lines were performed in parallel and at the end of treatment media were removed and cells or cell extracts were analysed.

\section{Immunofluorescence assay}

We performed an immunofluorescence assay to explore the effect of NF- $\kappa \mathrm{B}$ inhibitor on the acidic bileinduced nuclear translocation of NF- $\kappa \mathrm{B}$ transcription factor p65, phosphorylated at Ser536, linked to NF$\kappa \mathrm{B}$ activation mediated by $\mathrm{IKKb}$ and/or IKKa [46].
Cytokeratin 14 (CK14) was used to reveal the cytoplasmic cellular compartment of the treated cells. HHPC were grown on slides (multiwall chamber slides; Lab-Tek ${ }^{\circledR}$ ) and underwent repeated exposure with experimental and control fluids with or without NF- $\kappa \mathrm{B}$ inhibitor (10 $\mu \mathrm{M}$ of BAY 11-7082). At the end of treatment, cells were fixed immediately after the final treatment in $4 \%$ paraformaldehyde (Sigma-Aldrich) for 7 minutes and incubated with 1:65 of primary anti-NF- $\kappa \mathrm{B}$ (rabbit polyclonal anti-phospho-p65 Ser536, AbD Serotec, BIORAD, CA, USA), overnight at $4{ }^{\circ} \mathrm{C}$, after permeabilization of cell membranes using $0.2 \%$ Triton X100 (AmericanBio, Natick, MA, USA) in PBS for 2-3 minutes and blocking with $2 \%$ bovine serum albumin (BSA) in PBS (SigmaAldrich, USA) for 1 hour. The next day, cells first were washed in 1\% Tween20 (AmericanBio, Natick, MA, USA) in PBS for 1-2 min, then with $0.1 \%$ BSA in PBS twice for $5 \mathrm{~min}$ and subsequently were incubated with 1:500 dilutions of secondary anti-rabbit DyLight ${ }^{\circledR} 488$ (green; Vector Labs, USA), for 1 hour, at room temperature. Cells were washed and incubated with 1:50 primary anti-cytokeratin 14 (mouse monoclonal Ab, LL002, abcam $^{\circledR}$, MA, USA) overnight at $4^{\circ} \mathrm{C}$. The next day cells were washed and incubated with 1:500 secondary

\section{Common BAY 11-7082-induced mRNA phenotype in HHK and HHPC}

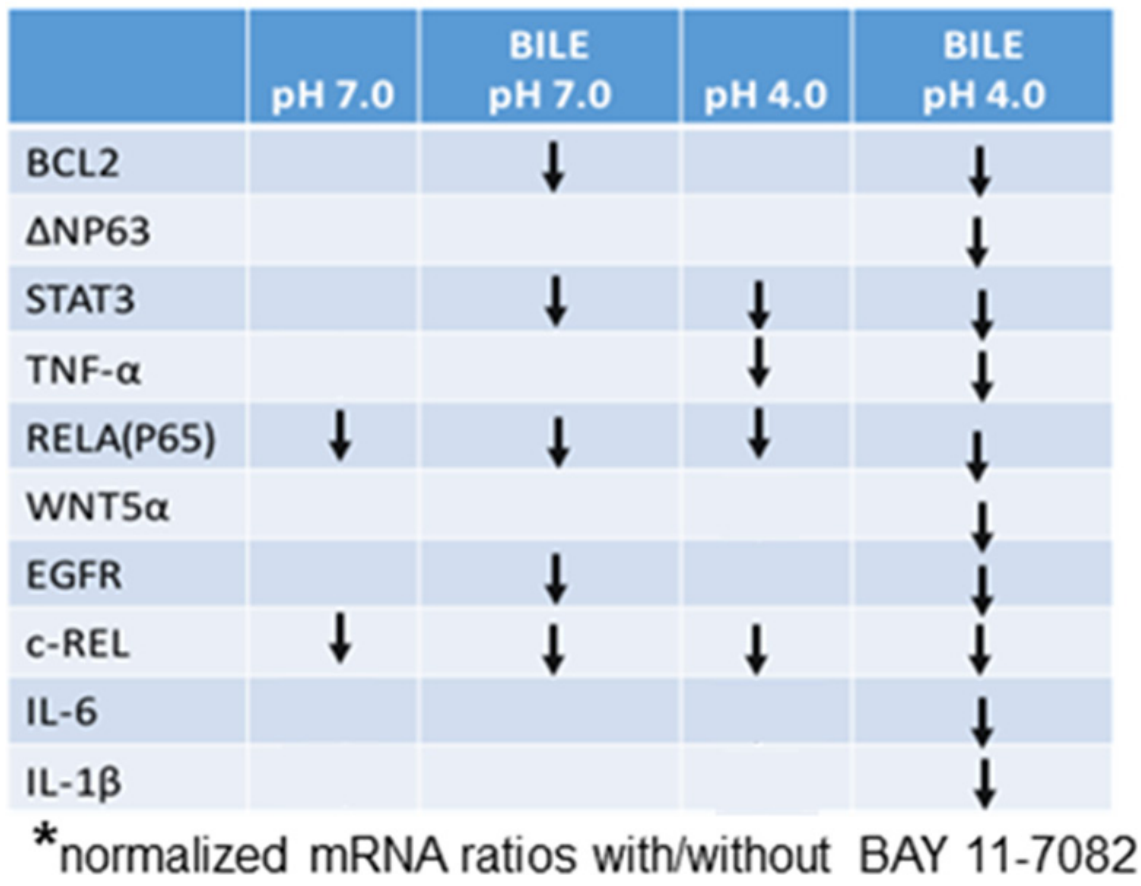

Figure 8: BAY 11-7082-induced common mRNA phenotype in treated normal human hypopharyngeal cells. Table describes BAY 11-7082-induced common mRNA phenotypes (relative reduced mRNA levels of genes in cells exposed to BAY 11-7082 compared to those treated without BAY 11-7082) in bile at $\mathrm{pH} 4.0$, bile at $\mathrm{pH} 7.0$, acid at $\mathrm{pH} 4.0$ and control at $\mathrm{pH} 7.0$ treated normal human hypopharyngeal cells (HHPC and HHK). We demonstrate that the acidic bile group produces a reduced mRNA phenotype for all analyzed genes in the presence of BAY 11-7082. In contrast, acid alone $(\mathrm{pH} 4.0)$, bile at $\mathrm{pH} 7.0$ and control at $\mathrm{pH} 7.0$ treated groups demonstrate a reduced mRNA phenotype only in a part of the analyzed genes. 


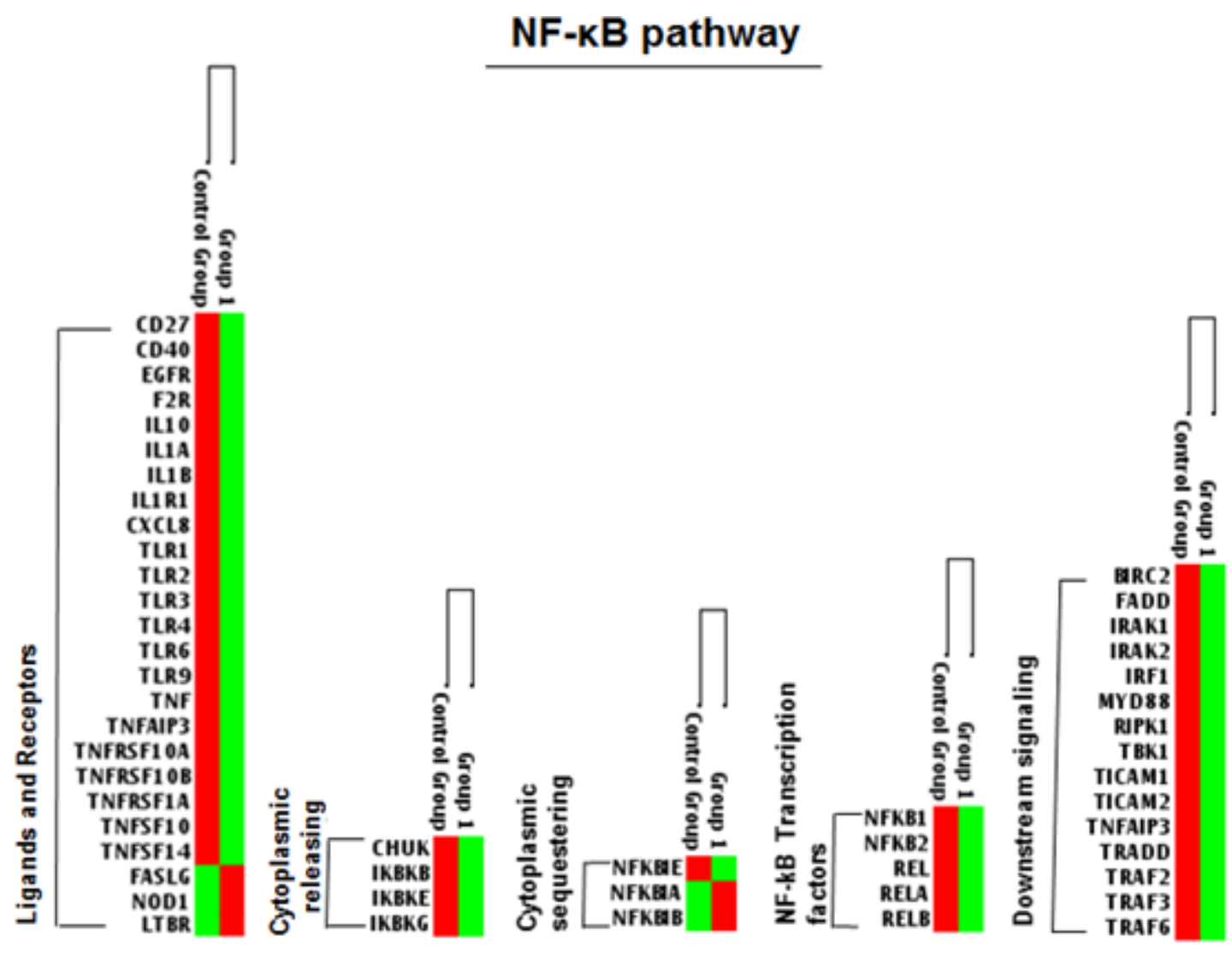

\section{NF-KB responsive genes}
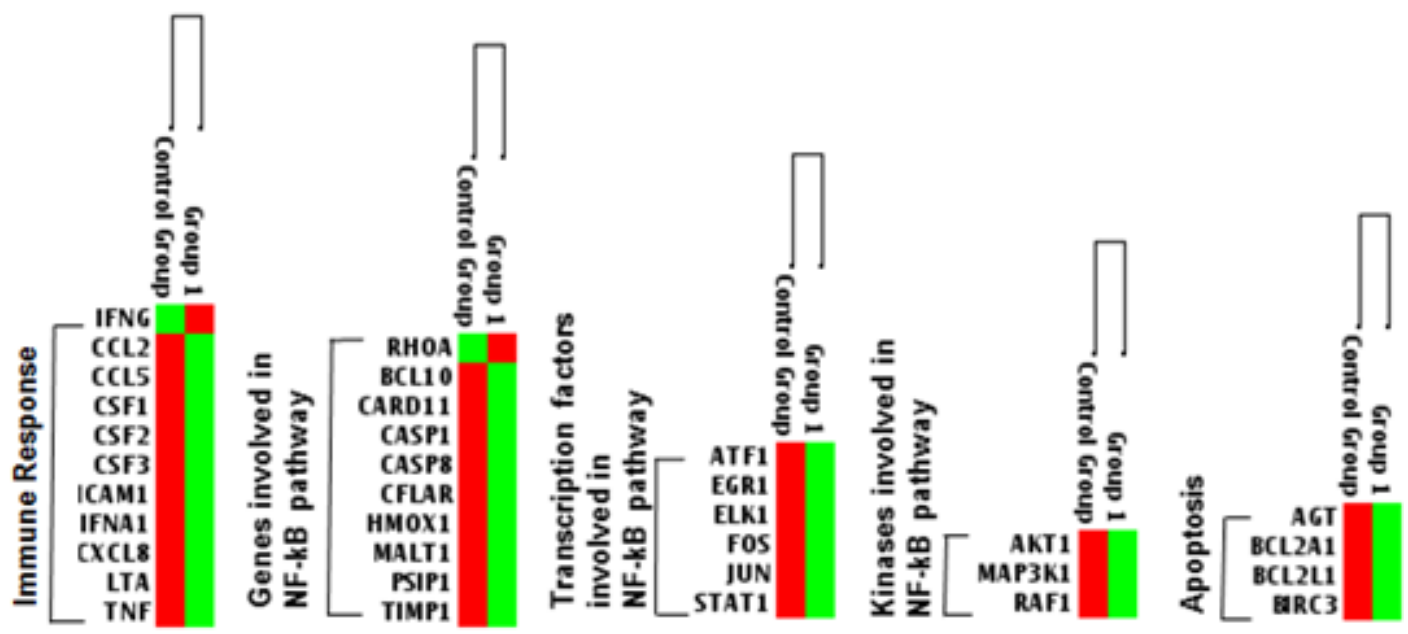

Group 1: Acidic bile (pH 4.0)+BAY 11-7082 Control Group: Acidic bile ( $\mathrm{pH} 4.0$ )

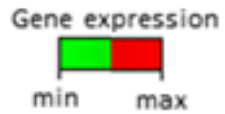

Figure 9: BAY 11-7082 reduced the acidic bile-induced gene expression profiling of NF- $\kappa B$ signaling pathway in treated normal human hypopharyngeal cells. Heat maps were obtained by RT2²-Profiler PCR array analysis for NF- $\mathrm{kB}$ signaling. The genes were clustered based on their biological role. The heat maps demonstrated the effect of BAY 11-7082 in gene expression of NF-KB pathway and NF- $\mathrm{kB}$ responsive genes (red color for maximum expression and green for minimum). Group 1: Acidic bile-treated cells with BAY 117082; Control Group: Acidic bile-treated cells without BAY 11-7082. (Gene expression has been normalized to two housekeeping genes; hGAPDH, human glyceraldehyde-3-phosphate dehydrogenase and RPLP0, ribosomal protein lateral stalk subunit P0). 
anti-mouse DyLight ${ }^{\circledR} 650$ (red; Vector Labs, USA), for 1 hour, at room temperature, washed and mounted using Prolong Gold Mountant with diamidino-phenylindole (ProLong ${ }^{\circledR}$ Diamond Antifade Mountant with DAPI; Life Technologies, Thermo Scientific, MA, USA) for nuclear staining and mounting of cells (blue). The slides were examined using a Zeiss Confocal microscope and images were captured and analysed using Zen imaging software from Carl Zeiss, microscopy (Germany). Total p-p65 (S536) expression levels in treated HHPC with/without $\mathrm{NF}-\kappa \mathrm{B}$ inhibitor were identified by fluorescence intensity (mean \pm SD bin count) of two independent images $(\geq 10$ cells) (Zen imaging software).

\section{Western blotting}

We performed western blot analysis, as described previously and included in the Supplementary information online, to determine the protein expression levels of NF$\kappa \mathrm{B}$ (p65), phospho-inhibitor kappaB- $\alpha$ (p-IкB- $\alpha)$ and bcl2 , in treated human hypopharyngeal primary cells (HHPC) and human hypopharyngeal keratinocytes (HHK) with and without NF-אB inhibitor, BAY 11-7082. Specifically, we isolated cytoplasmic and nuclear fractions from treated cells at the end of three independent experiments, using NE-PER nuclear and cytoplasmic extraction, including protease inhibitors (Thermo Scientific, Pierce, NY). We measured the total cytoplasmic and nuclear protein concentrations of cell extracts using the BCA-200 Protein Assay kit (Thermo Scientific). We used anti-NF-кB (rabbit polyclonal anti-phospho-p65 Ser536, AbD Serotec, BIORAD, CA, USA)), phospho-IкB- $\alpha$ Ser32/36 (5A5; Cell Signaling, EMD Millipore, Billerica, MA), and bcl2 (C-2; Santa Cruz Biotechnology) and $\beta$-actin (C4; Santa Cruz Biotechnology) for cytoplasmic extracts and Histone 1 (AE-4; Santa Cruz Biotechnology) for nuclear extracts normalization. Protein levels were quantified by Gel imaging system (BIO-RAD) in each nuclear and cytoplasmic cellular compartment, and expression levels were estimated by Image Lab 5.2 analysis software ( $B I O-$ $R A D)$, as described in Supplementary information online.

\section{Luciferase assay}

We performed a luciferase assay in order to monitor the activity of the NF- $\kappa \mathrm{B}$ in HHPC and HHK exposed to bile with or without the pharmacologic inhibitor of NF$\kappa \mathrm{B}$, BAY 11-7082. We used Dual-Glo ${ }^{\circledR}$ Luciferase Assay system (Promega Corporation, Madison, WI, USA), Lipofectamine $^{\circledR} 2000$ (Invitrogen $^{\mathrm{TM}}$ ), and a plasmid containing firefly luciferase gene under the control of NF$\kappa \mathrm{B}$ responsive element (NF- $\mathrm{kB}$ reporter, $3 \mathrm{kB}-\mathrm{ConA}-\mathrm{luc})$ or a plasmid containing firefly luciferase gene without any additional response elements (ConA-luc, reference control plasmid) [23], in accordance with the manufacturer's procedure. The treatment was performed 24 hours after transfection. We performed triplicate assays for each treatment condition (bile with or without NF- $\mathrm{kB}$ Inhibitor and corresponding controls, at $\mathrm{pH} 4.0$ and $\mathrm{pH} 7.0$ ). The cells were treated once for $30 \mathrm{~min}$ and followed after 5-6 hours by an additional $10 \mathrm{~min}$ treatment. This was performed 2 times/day, constituting a regimen of repetitive exposures. At the end of the final treatment, luminescence was measured using a luminometer (Infinite ${ }^{\circledR}$ M1000 PRO, TECAN) and i-control ${ }^{\mathrm{TM}}$ software. We expressed NF- $\mathrm{\kappa B}$ activity as ratios of mean values (values for NF- $\mathrm{KB}$ reporter, 3kBConA-luc, against the mean value for reference control, conA-luc) calculated in treated HHPC and HHK for each condition. Finally, we expressed the alterations of NF- $\kappa B$ activity induced by BAY 11-7082 as ratios of relative NF$\kappa \mathrm{B}$ activity (with/without NF- $\mathrm{B}$ inhibitor).

\section{Quantitative real time PCR}

We isolated total RNA (RNeasy mini kit; Qiagen Inc., CA, USA) from HHK and HHPC exposed to GDF with or without BAY 11-7082, and corresponding controls, to evaluate the transcriptional levels of RELA (p65), c-REL, bcl-2, TNF- $\alpha, \Delta$ Np63, EGFR, STAT3, WNT5A, IL-1 $\beta$ and IL-6, using quantitative real time polymerase chain reaction (qPCR) analysis, as previously described [21]. Briefly, we determined RNA quality and concentration by absorption ratios at 260/280 $\mathrm{nm}(>2.0)$ and $260 \mathrm{~nm}$, respectively (NanoDrop ${ }^{\mathrm{TM}} 1000$ spectrophotometer; Thermo Fisher Scientific, Waltham, MA). We performed reverse transcription (iScript cDNA synthesis kit; Bio-Rad) and real time qPCR analysis (Bio-Rad real time thermal cycler CFX96TM; Bio-Rad) using specific primers for target genes and reference housekeeping gene, human glyceraldehyde 3-phosphate dehydrogenase ( $h \mathrm{GAPDH})$ (Supplementary Table 1; see Supplementary information online), (QuantiTect Primers Assays; Qiagen), and $\mathrm{iQ}^{\mathrm{TM}}$ SYBR Green Supermix (Bio-Rad). We performed assays in 96-well plates, in triplicate for each sample, and data were analyzed by $\mathrm{CFX} 96^{\mathrm{TM}}$ software. Relative mRNA expression levels were estimated for each target gene relative to reference gene $(\Delta \Delta C \mathrm{t})$. (Data were obtained from three independent experiments)

\section{Statistical analysis}

Statistical analysis was performed using GraphPad Prism 6 software and ONE-WAY ANOVA (Friedman or Kruskal-Wallis and Dunn's multiple analysis test; $p$-values $<0.05$ ) as well as $t$-test analysis (multiple comparisons by Holm-Sidak) to reveal any evidence of statistically significant reductions in protein or mRNA expression levels in different experimental and control groups treated by BAY 11-7082. We performed Pearson correlation to estimate the correlation coefficient between expression levels of different groups ( $p$-values $<0.05)$. Specifically, we used Pearson analysis to identify correlations between the BAY 11-7082-induced 
transcriptional levels of the analyzed NF- $\mathrm{\kappa B}$ transcriptional factor, RELA (p65) and NF- $\mathrm{kB}$ related genes, in the four different groups of treated HHK and HHPC.

\section{PCR array for NF- $\mathrm{B}$ signaling pathway}

We performed a PCR microarray analysis of the NF$\kappa \mathrm{B}$ signaling pathway in acidic bile treated groups with and without BAY 11-7082 to identify the effect of NF$\kappa \mathrm{B}$ inhibitor on the acidic bile-induced gene expression profiling of the NF- $\mathrm{BB}$ signaling pathway. Specifically, we used a transcriptome of human hypopharyngeal keratinocytes and a PCR array kit for human NF- $\kappa B$ signaling pathway ( $\mathrm{RT}^{2}$-Profiler PCR array, PAHS-025z; SABiosciences, Qiagen), following the manufacturer's instructions. The data were analyzed online by $\mathrm{RT}^{2}-$ Profiler PCR Array Data Analysis version 3.5 software and differential expression of more than 2-fold-change of gene expression (up and down regulation) was estimated between the acidic bile-treated group (control) and acidic bile-treated with inhibitor group (Group 1).

\section{Data availability}

The datasets generated during and/or analyzed during the current study are available from the corresponding author on reasonable request.

\section{CONCLUSIONS}

We describe a successful in vitro model of NF$\kappa \mathrm{B}$ inhibition, using BAY 11-7082, in acidic biletreated normal human hypopharyngeal cells. We have demonstrated that the presence of BAY 11-7082 significantly reduces the overexpression of NF- $\kappa B$ transcriptional factors and NF- $\mathrm{KB}$ related genes with oncogenic function, such as EGFR, TNF- $\alpha$ and STAT3, as well as IL-1 $\beta$ and IL-6, previously linked to acidic bile in early premalignant hypopharyngeal lesions. Additionally, NF- $\mathrm{kB}$ inhibition diminishes the transcriptional activation of anti-apoptotic bcl-2 and cell proliferation marker $\triangle \mathrm{Np} 63$ and WNT5 $\alpha$ linked to epithelial mesenchymal transition pathways.

In summary, our novel findings firstly demonstrate that NF-KB inhibition in our model effectively prevents the acidic bile-induced and cancer-related mRNA phenotype and reduces effects of the acidic bile-induced NF- $\mathrm{KB}$ signaling pathway, further demonstrating that $\mathrm{NF}-\mathrm{\kappa B}$ is a critical link between acidic bile and early preneoplastic events. In vivo investigation of NF- $\mathrm{KB}$ inhibition in acidic bile-treated hypopharyngeal mucosa, supported by future global molecular sequencing analysis, may provide insights into the effective prevention of the induced premalignant phenotype and deregulated oncogenic signaling pathways, previously linked to HNSCC [36]. In future studies, we will also explore non-pharmaceutical
NF- $\kappa \mathrm{B}$ inhibitors, such as dietary curcumin and others with considered potential clinical application. These observations may further contribute to prevention or therapeutic interventions of extra-esophageal refluxrelated laryngopharyngeal neoplasia.

\section{Author contributions}

Conceptualization: DV CTS; Data curation: DV SD CTS; Formal analysis: DV, SD; Funding acquisition: CTS; Investigation: DV CTS SD; Methodology: DV; Project administration: CTS; Resources: CTS DV; Software: DV; Supervision: CTS DV; Validation: DV SD CTS; Visualization: DV; Writing-original draft: DV CTS; Writing-review \& editing: CTS DV SD.

\section{CONFLICTS OF INTEREST}

The authors whose names are listed in this article certify that they have NO affiliations with or involvement in any organization or entity with any financial interest, or non-financial interest in the subject matter or materials discussed in this manuscript.

\section{GRANT SUPPORT}

This study was supported by the Virginia Alden Wright Fund.

\section{REFERENCES}

1. Hashibe M, Boffetta P, Zaridze D, Shangina O, SzeszeniaDabrowska N, Mates D, Fabiánová E, Rudnai P, Brennan P. Contribution of tobacco and alcohol to the high rates of squamous cell carcinoma of the supraglottis and glottis in Central Europe. Am J Epidemiol. 2007; 165:814-820.

2. Curado MP, Hashibe M. Recent changes in the epidemiology of head and neck cancer. Curr Opin Oncol. 2009; 21:194-200.

3. Talamini R, Bosetti C, La Vecchia C, Dal Maso L, Levi F, Bidoli E, Negri E, Pasche C, Vaccarella S, Barzan L, Franceschi S. Combined effect of tobacco and alcohol on laryngeal cancer risk: a case-control study. Cancer Causes Control. 2002; 13:957-964.

4. Tutar H, Erdamar H, Köybasioglu A, Dinc AE, Ceylan A, Uslu S. Can bile acids be an etiological factor for laryngeal carcinoma? ORL J Otorhinolaryngol Relat Spec. 2011; 73:156-161.

5. Sereg-Bahar M, Jerin A, Hocevar-Boltezar I. Higher levels of total pepsin and bile acids in the saliva as a possible risk factor for early laryngeal cancer. Radiol Oncol. 2015; 49:59-64.

6. Galli J, Calò L, Agostino S, Cadoni G, Sergi B, Cianci $\mathrm{R}$, Cammarota G. Bile reflux as possible risk factor in laryngopharyngeal inflammatory and neoplastic lesions. Acta Otorhinolaryngol Ital. 2003; 23:377-382. 
7. Kauer WK, Peters JH, DeMeester TR, Ireland AP, Bremner CG, Hagen JA. Mixed reflux of gastric and duodenal juices is more harmful to the esophagus than gastric juice alone. The need for surgical therapy re-emphasized. Ann Surg. 1995; 222:525-31.

8. McQuaid KR, Laine L, Fennerty MB, Souza R, Spechler SJ. Systematic review: the role of bile acids in the pathogenesis of gastro-oesophageal reflux disease and related neoplasia. Aliment Pharmacol Ther. 2011; 34:146-165.

9. Nehra D, Howell P, Williams CP, Pye JK, Beynon J. Toxic bile acids in gastro-oesophageal reflux disease: influence of gastric acidity. Gut. 1999; 44:598-602.

10. Covington MF, Krupinski E, Avery RJ, Kuo PH. Classification schema of symptomatic enterogastric reflux utilizing sincalide augmentation on hepatobiliary scintigraphy. J Nucl Med Technol. 2014; 42:198-202.

11. Nottingham LK, Yan CH, Yang X, Si H, Coupar J, Bian Y, Cheng TF, Allen C, Arun P, Gius D, Dang L, Van Waes C, Chen $\mathrm{Z}$. Aberrant IKK $\alpha$ and IKK $\beta$ cooperatively activate $\mathrm{NF}-\kappa \mathrm{B}$ and induce EGFR/AP1 signaling to promote survival and migration of head and neck cancer. Oncogene. 2014; 33:1135-1147.

12. Stadler ME, Patel MR, Couch ME, Hayes DN. Molecular biology of head and neck cancer: risks and pathways. Hematol Oncol Clin North Am. 2008; 22:1099-1124.

13. Molinolo AA, Amornphimoltham P, Squarize $\mathrm{CH}$, Castilho RM, Patel V, Gutkind JS. Dysregulated molecular networks in head and neck carcinogenesis. Oral Oncol. 2009; 45:324-334.

14. King KE, Ponnamperuma RM, Allen C, Lu H, Duggal P, Chen Z, Van Waes C, Weinberg WC. The p53 homologue DeltaNp63alpha interacts with the nuclear factor-kappaB pathway to modulate epithelial cell growth. Cancer Res. 2008; 68:5122-5131.

15. Jackson-Bernitsas DG, Ichikawa H, Takada Y, Myers JN, Lin XL, Darnay BG, Chaturvedi MM, Aggarwal BB. Evidence that TNF-TNFR1-TRADD-TRAF2-RIP-TAK1IKK pathway mediates constitutive NF-kappaB activation and proliferation in human head and neck squamous cell carcinoma. Oncogene. 2007; 26:1385-1397.

16. Dong J, Jimi E, Zeiss C, Hayden MS, Ghosh S. Constitutively active NF-kappaB triggers systemic TNFalpha-dependent inflammation and localized TNFalpha-independent inflammatory disease. Genes Dev. 2010; 24:1709-1717.

17. Foxwell BM, Bondeson J, Brennan F, Feldmann M. Adenoviral transgene delivery provides an approach to identifying important molecular processes in inflammation: evidence for heterogenecity in the requirement for NF-kB in tumour necrosis factor production. Ann Rheum Dis. 2000; 59:i54-59.

18. Guyer RA, Macara IG. Loss of the polarity protein PAR3 activates STAT3 signaling via an atypical protein kinase $\mathrm{C}(\mathrm{aPKC}) / \mathrm{NF}-\kappa \mathrm{B} /$ interleukin-6 (IL-6) axis in mouse mammary cells. J Biol Chem. 2015; 290:8457-8468.
19. Zhao Y, Zhang C, Huang Y, Yu Y, Li R, Li M, Liu N, Liu P, Qiao J. Up-regulated expression of WNT5a increases inflammation and oxidative stress via $\mathrm{PI} 3 \mathrm{~K} / \mathrm{AKT} / \mathrm{NF}-\kappa \mathrm{B}$ signaling in the granulosa cells of PCOS patients. J Clin Endocrinol Metab. 2015; 100:201-211.

20. Bo H, Zhang S, Gao L, Chen Y, Zhang J, Chang X, Zhu M. Upregulation of Wnt5a promotes epithelial-to-mesenchymal transition and metastasis of pancreatic cancer cells. BMC Cancer. 2013; 13:496.

21. Sasaki CT, Issaeva N, Vageli DP. In vitro model for gastroduodenal reflux-induced nuclear factor-kappaB activation and its role in hypopharyngeal carcinogenesis. Head Neck. 2016; 38:E1381-91.

22. Vageli DP, Prasad ML, Sasaki CT. Gastro-duodenal fluid induced nuclear factor-карраB activation and early premalignant alterations in murine hypopharyngeal mucosa. Oncotarget. 2016; 7:5892-908. https://doi.org/10.18632/ oncotarget. 6824.

23. Sasaki CT, Toman J, Vageli D. The In Vitro Effect of Acidic-Pepsin on Nuclear Factor KappaB Activation and Its Related Oncogenic Effect on Normal Human Hypopharyngeal Cells. PLoS One. 2016; 11:e0168269.

24. Ulualp SO, Roland PS, Toohill RJ, Shaker R. Prevalence of gastroesophagopharyngeal acid reflux events: an evidencebased systematic review. Am J Otolaryngol. 2005; 26:239244.

25. Dvorak K, Payne CM, Chavarria M, Ramsey L, Dvorakova B, Bernstein H, Holubec H, Sampliner RE, Guy N, Condon A, Bernstein C, Green SB, Prasad A, Garewal HS. Bile acids in combination with low $\mathrm{pH}$ induce oxidative stress and oxidative DNA damage: relevance to the pathogenesis of Barrett's oesophagus. Gut. 2007; 56:763-771.

26. Lee TL, Yang XP, Yan B, Friedman J, Duggal P, Bagain L, Dong G, Yeh NT, Wang J, Zhou J, Elkahloun A, Van Waes $\mathrm{C}$, Chen Z. A novel nuclear factor-kappaB gene signature is differentially expressed in head and neck squamous cell carcinomas in association with TP53 status. Clin Cancer Res. 2007; 13:5680-5691.

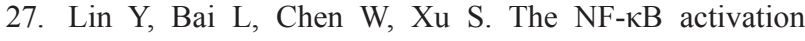
pathways, emerging molecular targets for cancer prevention and therapy. Expert Opin Ther Targets. 2010; 14:45-55.

28. Pierce JW, Schoenleber R, Jesmok G, Best J, Moore SA, Collins T, Gerritsen ME. Novel inhibitors of cytokine-induced IkappaBalpha phosphorylation and endothelial cell adhesion molecule expression show anti-inflammatory effects in vivo. J Biol Chem. 1997; 272:21096-210103.

29. Nakanishi C, Toi M. Nuclear factor-kappaB inhibitors as sensitizers to anticancer drugs. Nat Rev Cancer. 2005; 5:297-309.

30. Meng Z, Lou S, Tan J, Xu K, Jia Q, Zheng W. Nuclear factor-kappa $\mathrm{B}$ inhibition can enhance apoptosis of differentiated thyroid cancer cells induced by 131I. PLoS One. 2012; 7: e33597.

31. Allen CT, Ricker JL, Chen Z, Van Waes C. Role of activated nuclear factor-kappaB in the pathogenesis and therapy of 
squamous cell carcinoma of the head and neck. Head Neck. 2007; 29:959-971.

32. Loercher A, Lee TL, Ricker JL, Howard A, Geoghegen J, Chen Z, Sunwoo JB, Sitcheran R, Chuang EY, Mitchell JB, Baldwin AS Jr, Van Waes C. Nuclear factor-kappaB is an important modulator of the altered gene expression profile and malignant phenotype in squamous cell carcinoma. Cancer Res. 2004; 64:6511-6523.

33. Hoesel B, Schmid JA. The complexity of NF-kB signaling in inflammation and cancer. Mol Cancer. 2013; 12:86.

34. Karin M, Lin A. NF-kappaB at the crossroads of life and death. Nat Immunol. 2002; 3:221-227.

35. Vander Broek R, Snow GE, Chen Z, Van Waes C. Chemoprevention of head and neck squamous cell carcinoma through inhibition of NF- $\mathrm{kB}$ signaling. Oral Oncol. 2014; 50:930-941.

36. Assimakopoulos D, Patrikakos G. The role of gastroesophageal reflux in the pathogenesis of laryngeal carcinoma. Am J Otolaryngol. 2002; 23:351-357.

37. Sasaki CT, Marotta J, Hundal J, Chow J, Eisen RN. Bileinduced laryngitis: is there a basis in evidence? Ann Otol Rhinol Laryngol. 2005; 114:192-197.

38. Yu L, Mu Y, Sa N, Wang H, Xu W. Tumor necrosis factor $\alpha$ induces epithelial-mesenchymal transition and promotes metastasis via NF- $\mathrm{BB}$ signaling pathway-mediated TWIST expression in hypopharyngeal cancer. Oncol Rep. 2014; 31:321-327.

39. Lee TL, Yeh J, Friedman J, Yan B, Yang X, Yeh NT, Van Waes C, Chen Z. A signal network involving coactivated NF-kappaB and STAT3 and altered p53 modulates BAX/ BCL-XL expression and promotes cell survival of head and neck squamous cell carcinomas. Int J Cancer. 2008; 122:1987-1998.
40. Squarize CH, Castilho RM, Sriuranpong V, Pinto DS, Gutkind JS. Molecular cross-talk between the NFkappaB and STAT3 signaling pathways in head and neck squamous cell carcinoma. Neoplasia. 2006; 8:733-746.

41. Lu H, Yang X, Duggal P, Allen CT, Yan B, Cohen J, Nottingham L, Romano RA, Sinha S, King KE, Weinberg WC, Chen Z, Van Waes C. TNF- $\alpha$ promotes c-REL/ $\Delta \mathrm{Np} 63 \alpha$ interaction and TAp73 dissociation from key genes that mediate growth arrest and apoptosis in head and neck cancer. Cancer Res. 2011; 71:6867-6877.

42. Yang X, Lu H, Yan B, Romano RA, Bian Y, Friedman J, Duggal P, Allen C, Chuang R, Ehsanian R, Si H, Sinha S, Van Waes $C$, et al. $\triangle \mathrm{Np} 63$ versatilely regulates a Broad $\mathrm{NF}-\kappa \mathrm{B}$ gene program and promotes squamous epithelial proliferation, migration, and inflammation. Cancer Res. 2011; 71:3688-3700.

43. Lamouille S, Xu J, Derynck R. Molecular mechanisms of epithelial-mesenchymal transition. Nat Rev Mol Cell Biol. 2014; 15:178-196.

44. Katoh M, Katoh M. Transcriptional mechanisms of WNT5A based on NF-kappaB, Hedgehog, TGFbeta, and Notch signaling cascades. Int J Mol Med. 2009; 23:763-769.

45. Ayazi S, Hagen JA, Zehetner J, Oezcelik A, Abate E, Kohn GP, Sohn HJ, Lipham JC, Demeester SR, Demeester TR. Proximal esophageal $\mathrm{pH}$ monitoring: improved definition of normal values and determination of a composite $\mathrm{pH}$ score. $\mathrm{J}$ Am Coll Surg. 2010; 210:345-350.

46. Sakurai H, Chiba H, Miyoshi H, Sugita T, Toriumi W. IkappaB kinases phosphorylate NF-kappaB p65 subunit on serine 536 in the transactivation domain. J Biol Chem. 1999; 274:30353-30356. 